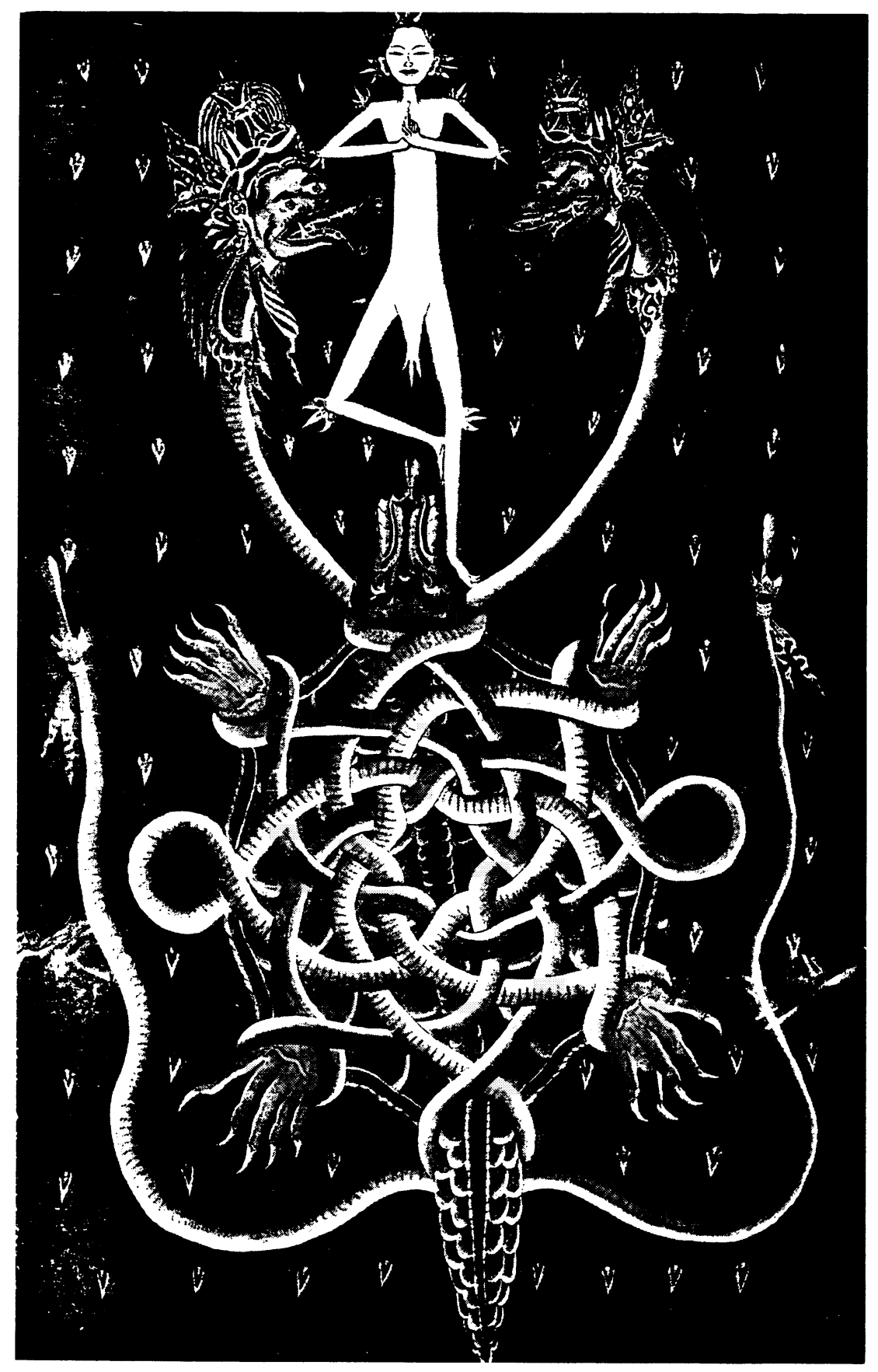

THE BALINESE COSMOS 


\title{
MARGARET MEAD'S BALINESE: THE FITTING SYMBOLS OF THE AMERICAN DREAM ${ }^{1}$
}

\author{
Tessel Pollmann
}

Bali celebrates its day of consecrated silence. It is Nyepi, New Year. It is 1936. Nothing disturbs the peace of the rice-fields; on this day, according to Balinese adat, everybody has to stay in his compound. On the asphalt road only a patrol is visible-Balinese men watching the silence. And then-unexpected-the silence is broken. The thundering noise of an engine is heard. It is the sound of a motorcar. The alarmed patrollers stop the car. The driver talks to them. They shrink back: the driver has told them that he works for the KPM. The men realize that they are powerless. What can they do against the

\footnotetext{
${ }^{1}$ I want to express my gratitude to Dr. Henk Schulte Nordholt (University of Amsterdam) who assisted me throughout the research and the writing of this article. The interviews on Bali were made possible by Geoffrey Robinson who gave me in Bali every conceivable assistance of a scholarly and practical kind. The assistance of the staff of Olin Libary, Cornell University was invaluable.

For this article I used the following general sources: Gregory Bateson and Margaret Mead, Balinese Character: A Photographic Analysis (New York: New York Academy of Sciences, 1942); Geoffrey Gorer, Bali and Angkor, A 1930's Trip Looking at Life and Death (Singapore: Oxford University Press, 1987); Jane Howard, Margaret Mead, a Life (New York: Simon and Schuster, 1984); Colin McPhee, A House in Bali (Oxford: Oxford University Press, 1979; orig. 1944); Margaret Mead, Blackberry Winter, My Early Years (New York: Washington Square Press, 1975); Margaret Mead, Letters from the Field, 1925-1975, ed. Ruth Nanda Ashen (New York: Harper \& Row, 1977); Margaret Mead and Walter Spies, Correspondence, Rijksuniversiteit Leiden, University Library; Wijnand Otto Jan Nieuwenkamp, W.O.J.N., leven en werken, bouwen en zwerven van de kunstenaar W.O.J. Nieuwenkamp opgetekend door zijn kleinzoon (Utrecht: Bruna, 1979); Mary Pos, Werkelijkheid op Bali (The Hague: van Hoeve, 1940); Hickman Powell, The Last Paradise (Oxford: Oxford University Press, 1982; orig.1930); Hans Rhodius and John Darling, Walter Spies and Balinese Art, ed. John Stowell (Zutphen: Tropical Museum, 1980); H. Schulte Nordholt, "Een Balische Dynastie: Hiërarchie en conflict in de Negara Mengwi 1700-1940" (PhD dissertation, Vrije Universiteit Amsterdam, 1988); Walter Spies, Schönheit und Reichtum des Lebens Walter Spies, Musiker und Maler 1895-1942, eine autobiographie in Briefen und Erinnerungen, ed. Hans Rhodius (The Hague: Boucler, 1964); Adrian Vickers, Bali: A Paradise Created (Ringwood: Penguin Books, 1989); Beryl Zoete and Walter Spies, Dance and Drama in Bali (Kuala Lumpur: Oxford University Press 1982; orig. 1938).
} 
KPM? The KPM "owns Bali more or less" reports a contented Margaret Mead a few weeks later in a letter home. ${ }^{2}$

The KPM is the Koninklijke Paketvaart Maatschappij; it is the shipping company that has a monopoly of the official trade between the islands of the Dutch-Indies archipelago. The KPM is closely connected to the Government in Batavia, Java. The KPM is the owner of the modern Bali Hotel in Denpasar, situated at the spot where in 1906 the puputan took place. The KPM is the employer of Balinese personnel. The agent of the KPM in Bali is Bobbie Mörzer Bruyns. Formally he is a businessman. By the Balinese he is regarded as a civil servant of the colonial Government. The Balinese tend to see all white people as Dutch and all Dutch as civil servants. And they are very afraid of civil servants. ${ }^{3}$

So that's the way the passengers of the KPM-motorcar, Dr. Margaret Mead and her husband Dr. Gregory Bateson, arrive in Bali, on Balinese New Year 1936. They're on their way to Walter Spies, painter, writer, musician, director of the Bali Museum, lover of Jane Belo 4 and of young Balinese boys, friend of Bobbie Mörzer Bruyns for whose KPM tourist-brochure about Bali he makes beautiful photographs. The text in the brochure is by Dr. Rudolf Goris, Dutch scholar with the status of civil servant, who does research into Balinese culture and is living in Bali. Dr. Goris will be an important source on adat to Mead and Bateson in the following months.

In the house of Spies on their first day in Bali, Mead and Bateson meet Beryl de Zoete with whom Spies is working on his new book, Dance in Bali. It will turn out to be an important encounter. But as yet everything seems to be going smoothly. Spies, always the excellent host, has rented a furnished house and servants for Mead and Bateson. It is a ten-minute walk from his house. In her first letter home Mead writes enthusiastically about him:

Walter is a perfectly delightful person, an artist and a musician, who has lived in Bali for some eight years and has welcomed and entertained all the interesting people who come here. He has done a great deal to stimulate modern Balinese painting and has painted Bali himself and in general has worked out a most perfect relationship between himself, the island, its people and its traditions. ... Our only other neighbor here is a mild, responsible, only a little twinkling Dutch artist who supplies system and bookkeeping in Walter's attempts to protect and encourage the Balinese artists to resist the tourists and do good work. ${ }^{5}$

Walter Spies is clearly an attractive man. Born in 1895 as the son of the affluent German consul in Petersburg, he led a bohemian life in and out of Russia till during the Revolution he was interned. Since his liberation he has led the life of a young Berlin homosexual in a Christopher Isherwood atmosphere of art and travel. An inheritance from one of his friends makes him a rather independent man. Revolting against Europe and European art he looks for a new spiritual home. He departs for Asia, arrives in Indonesia, and settles in Bali in the late 1920s. He is interested in Balinese music and

\footnotetext{
${ }^{2}$ Mead, Letters from the Field, p. 158.

${ }^{3}$ Interview with I Made Tantra, Bali, May 1986, Denpasar, Bali. Subsequent statements by Mr. I Made Tantra, Ibu Gedong Bagus Oka, lbu Yasmin Oka, Idu Bagus Oka, Prof. Dr. Gde Ing Bagus, and Mr. Wijakusuma (see below especially pp. 18-22) were made to me in Denpasar in May 1986. The interview with Mr. I Made Kaler was done by Geoffrey Robinson.

${ }^{4}$ Walter Spies and Jane Belo, Correspondence, unpublished Rijksuniversiteit Leiden, University Library.
} 
transcribes it; he paints Balinese landscapes and sells his paintings; he collects art and becomes the curator of the new Bali Museum; he photographs and makes the prestigious KPM-brochure; he is well-mannered and shows the Governor-General the wonders of Balinese art during the latter's visit in 1937. He is one of the few foreigners in the DutchIndies who can get on with the typical Dutch civil servants who are provincial, thorough, and strict. Some of them, inevitably, envy Spies: his relations with Balinese people are better than theirs, and to foreigners he is a charming, cosmopolitan, and intelligent host. He attracts all the people who really do matter and who visit the island. And he manages his affairs rather well: he is not after money, but he has a talent for commerce. He organizes a cooperative of Balinese and Western painters that sells the betterquality paintings done in a small format and destined for the suitcases of tourists. ${ }^{6}$ At the same time he is a romantic who detests the influence of strangers on "his" Balinese. $\mathrm{He}$ is communicative, yet aloof. He is the center of "European" life in Bali, all whites in Balinese eyes being from Europe. He is impressive. He is the kind of man that is missed the moment he leaves a room. His contemporary Du Perron describes him as "a Balinese institution." But in 1937 he seems a tired man too; Du Perron not only finds him likable but also "kind of scattered which must have to do with Balinese tourism."7

His love for the natives is not contradicted by his quiet appreciation of colonialism. Colonialism as a paternalist protection against modernization he is not against. He rejoices when during the visit of the Governor-General in 1937 the administration forbids the natives to wear shirts and trousers. Bali in sarong for just one day is "natural" again, he writes home. In fact he is extracting for himself as well as for his native artistfriends the benefits of a well-organized, money-oriented modernizing society which has all the comforts of the West and all the charms of exoticism. At the same time he denies the existence of colonialism, pretending that in Bali nothing has changed. In Mead's words, he has "worked out a most perfect relationship" between himself and Bali. We hear the echoes of his ideas in Mead's first letter home:

I don't know what would be the best way to give you an idea of the contrasts here. It is the most extraordinary combination of a relatively untouched native life going along smoothly and quietly in its old way with a kind of extraneous, external civilization superimposed like an extra nervous system put on the outside of a body. Motor roads of black loose stones run through villages which are each protected by a magic wall against demons and over the heads of the motorists a screen of pointed bamboos is aimed at the demons. Along some of the roads on which people still carry all their rice-as it is taboo to move it by animal transport, a taboo that is now breaking down-there run telephone wires which connect all government offices with each other. From shady corners where a dozen men in sarongs may be comparing the virtues of fighting cocks in wicker cages, police in smart green uniforms and broadbrimmed straw hats may step out to ask your chauffeur for his driver's license. At a temple feast by the sea, where all the gods are brought in magnificent procession, held aloft in little sedan chairs shadowed by ceremonial umbrellas and preceded by women carrying pyramids of food and flowers shaped into offerings, one will see vendors of "ice candles." These are sticks on which ice has been frozen in the

\footnotetext{
${ }^{5}$ Mead, Letters from the Field, p. 160.

${ }^{6}$ G. Resink, "Cultuur op Bali," Bali en Lombokbode, December 4th 1946 (Collection of the Tropical Institute, Amsterdam).

7Edgar Du Perron, Verzameld Werk vol. 7 (Amsterdam: Van Oorschot, 1959), pp. 320-21.
} 
shape of candles and the vendors bring them in large thermos bottles strapped to bicycle bars. And at a theatrical performance at night, while some 500-year-old dance form is being executed, half the audience will be carrying flashlights.

But all this apparent "civilization" is on the surface and Bali seems to have learned through a couple of thousand years of foreign influences just how to use and how to ignore those influences. Accustomed to an alien aristocracy, accustomed to successive waves of Hinduism, Buddhism and so on, they let what is alien flow over their heads. ${ }^{8}$

This description of Balinese as timeless beings who are not changed and have no need for change fits exactly into the kind of anthropology Boas loved: that of customs. Just as Boas' own Indian informants seldom expressed resentment against American colonialism, so Mead's Balinese don't mind police in smart uniforms who control them with the help of telegraph wires-all things for which Balinese have no use, but for which they are heavily taxed. They are "above" minding about futilities like taxes and oppression; they are more interested in their culture. The question is: who invented that myth?

To answer that question we have to go back to 1906. In that year the South of Bali was conquered by the Dutch-the North having been already nominally under colonial rule for half a century. The conquering of the South is a bloody affair, and its pinnacle is the puputan by the Raja of Badung. In this ritual of large-scale murder and suicide, the Raja and hundreds of relatives, all dressed in white, kill each other and themselves before the eyes of the colonial soldiers. Amazed and shocked, the soldiers see the corpses falling upon each other or the victims exposing their bodies to the colonial army for the final, killing bullet. Afterwards, when the large heap of corpses is cleared away and the palace of the Raja is burning, the soldiers loot the treasures. But there is a man who is watching them: W. O. J. Nieuwenkamp, the artist who is working on his new, great, illustrious book that will be entitled: Bali and Lombok. This man is also the correspondent of an influential Dutch newspaper in the Netherlands. In his report to his newspaper he doesn't mention the looting, though he himself has personally saved a beautifully carved wooden door from the palace which was just about to serve as fuel for the soldiers' fire. In his letters to his wife he writes about his self-censorship: if he publishes what he has seen he will lose the sympathy of his sponsors: the National Ethnographic Museum, Queen Wilhelmina and Queen-Mother Emma, the Institute of Linguistics and Anthropology, the Society for the Advancement of Physical Research of the the Dutch Colonies, and wealthy Dutch private individuals. ${ }^{9}$ Four years later he receives his reward.

The puputan, as Nieuwenkamp rightly guessed, is not well received in the Netherlands. It is regarded as a shameful affair. After the victorious war against Lombok this shoddiness! Members of Parliament put questions to the responsible cabinet minister. An inquiry is promised, but never conducted. The affair cannot be denied, but given some time it can be comfortably hushed up. And hushed up it is. What comes in handy now is a scholarly description of Balinese society by the learned civil servant in North Bali, Liefrinck. ${ }^{10}$ It is a variation on the well-known colonial theme of the Southeast Asian "dessah" as the idyllic village-republic where the people are born democrats. In

\footnotetext{
${ }^{8}$ Mead, Letters from the Field, pp. 160-61.

${ }^{9}$ Nieuwenkamp, W.O.J.N. leven en werken, pp. 95, 100-101.

${ }^{10}$ F. A. Liefrinck, Bali en Lombok, geschriften (Amsterdam: s.a., 1927).
} 
the Balinese variation an important element that underlines Bali's uniqueness is added: all Balinese are born artists. That means it is not only in village life that they don't miss their rajas; in cultural-religious life, too, they can do without them. A genetic "argument" is added: Rajas are in fact Javanese by origin and thus imposters. Balinese culture doesn't need those imposters, rich in money as they may be. The real center of culture is not the palace, but the dessah. ${ }^{11}$

The first prestigious description after the puputan of the Balinese peasant as the autonomous villager who devotes his attention to the arts and the gods instead of to trivial things such as water, land, caste, women, and inheritance, has to do with Nieuwenkamp. The artist has finished his book about Bali and Lombok and wants to make a very beautiful, but very expensive edition of it. He asks for money-it is four years after the puputan. One of his subsidizers again is the Queen-Mother, Emma. As a member of the royal family she is restricted by the constitutional monarchy, and it is improbable that she would give money for Nieuwenkamp's book about the politically sensitive area Bali without consulting the experts. It is probable that Rouffaer was one of these: Dr. G. P. Rouffaer is in 1910 the future director of the Bali Instituut (1915), which is part of the Koloniaal Instituut, the "think-tank" of colonial cultural and agricultural policy. It is obvious that Rouffaer is involved with the financing of the book-he not only writes the introduction for it, but he in fact attacks the author in it. What has gone wrong? Nieuwenkamp has made a miscalculation: he has written in his text that, of course, Bali is beautiful, but the other isles in the lovely Dutch-Indies are beautiful as well. And he has stressed that not only does Bali have a shining culture, but that there are many isles in the archipelago with admirable cultures. He has gone even further: he has stressed that he, himself a craftsman, in Bali as elsewhere recognizes and loves the craft of, for example, the professional goldsmith, the professional weaver, or an exceptionally gifted sculptor. He has gone too far; a real Bali-lover denies that Balinese art, as all art, depends on the craftmanship of the professional artist. It is Rouffaer who rebukes him sternly, and who says to the reader: this fellow Nieuwenkamp is a nice artist and he makes beautiful drawings, but of course he is not a writer and he knows it himself. He, Rouffaer, will tell the real truth about Bali. The real truth is that Bali is incomparable, because unique. Balinese people are prosperous, happy, independent, autonomous, and they are all artists. Not just a few of them-all! It implies that all Balinese are the same, and that is precisely what Rouffaer wants to stress: those people have no stratified society in which, for example, Rajas play an important role. No, these Rajas can be killed and murdered, but to the real Bali it makes no difference. Rejoicing, he proclaims his praise of Bali, with as many capitals as an empire can spare: "And then the beautiful Richness of the people. This close harmony of Bali's riches with Bali's talents for the arts. Surely, it is true.... the Balinese are a forceful people, the best of the entire archipelago." Rouffaer lists the virtues and the qualities of the common people. He praises Balinese village-life and "its particular and collective cooperation." And he stresses the beauty of life in Bali: "What a Character, what a Style, what an Amount of Art Objects in all these Balinese products of Architecture, of Sculpture, of the fine Arts of Painting and drawing, of Metalwork, Weaving, Carving, Ceramics, Ornamental Art applied in nearly every way and in nearly every Material. Here is Folklife, the Folkreli-

11Vicky Baum, Liebe und Tod auf Bali (Amsterdam; Querido, 1937). 
gion and the Folkart are still of a beautiful wholeness, as formerly in Europe in the Gothic period in particular, and in the Renaissance also."12

The political impact is clear: the Dutch have done no harm to Bali. In the 1920s the Government will realize that without the Rajas the culture is going down the drain, and it then restores the hierarchy in a way that suits it, giving the Rajas considerable power over the natives, but not over the administration itself. This blurs, of course, the colonial picture of Bali as the island of folk-arts where the commonest peasant in his happy little village-republic is a connoisseur of art, yes, an artist himself who attends to his theatrical plays, his temple ceremonies, his dances, and his gamelan with attention and know-how, not needing any religious or cultural directive from above. This image is difficult to combine with the new emergence of the Rajas, but it is done, although in a forever blurred, imperfect way: in principle the Raja is still the imposter. In fact the white Resident in the 1920s in Bali doesn't dislike the good house, the good food, and the good gamelan of the imposter, and the compromise is that the Raja is seldom mentioned as being in essence the "bad guy" of Bali. The main character in the play remains the noble non-savage, the Balinese peasant. He is portrayed by Spies in the illusionist way the colonials love to see him portrayed. Spies expresses himself with a metaphor: life on Bali is an eternal birthday:

But my eternal birthday carries with it eternal gratitude. Because I believe in life and I believe in believing-and I play in life and I believe in the play. And that belief is a holy, serious fact. The delight, the holiness of life, even in the earnestness of daily life, with all its pits, attacks, exemptions, accidents, incidents in which I believe. And this belief reigns so strongly that it swallows all suffering, all-self-consciousness, all temporary, spatial and bodily circumstances, with the effect that only the great holiness of life is radiant. This is living a life, playing a life, being alive. And yet through this belief there is the distance from life. Life doesn't overwhelm me it doesn't [wash] me away, I don't drown in life's hopeless depths, and I find my way home from its seductive summits.... And for the Balinese too, because of his primitivity, his unspoiltness and his nearly complete harmony with nature, life is a holy fact. Religion is alive and is there to teach life, the holiness of life. Art here is not something that is outside life or outside religion. Here art is not art which one consumes like a sweet or a dessert for a change and to lighten the burden of a nearly unlivable life. No, life is what one can never enjoy sufficiently, and one tries by the prayer of art to accentuate the delight of life, to fix it in space or time... . That's why nearly every Balinese can paint, why nearly every Balinese can dance or play the gamelan the way he works in the sawah or feeds the pigs. And a woman makes in the same selfexplanatory way fantastic works of art for the offerings in the temple or she weaves the loveliest gold-brocades in the temple in the way she gives birth to a child, does the cooking or gossips with her neighbor. All is one and it is life and it is holy.

And they have that beautiful distance in their relation to life, they are above it, though they are as well part of it. And their art is not simply mirror-like, not realistic, not sentimental. All the feelings of love and hate, soulpain, jealousy, all that rubbish they have as we have it, but when they want to express themselves in an artistic way, all that is filtered, shifted, and it doesn't become a Sixth Symphony of Tschaikowsky, but a transparent and clear fact, in a way a formula, a nearly abstract

${ }^{12}$ G. P. Rouffaer, Preface in: W. O. J. Nieuwenkamp, Bali en Lombok. Zijnde een verzameling geillustreerde reisherinneringen en studiën omtrent land en volk, kunst en kunstnijverheid (Edam: Aan boord van De Zwerver, 1906-1910). 
formula in which the essence of life, of life in general, of the dynamics of an event are enclosed. All, all pure Song of Songs about the holiness of what is happening.

Bali is the opposite of Europe, he continues, because in Europe "the highest and noblest in human beings do not speak any more." Europe is dominated by "low instincts, its fallacies, its petty, dirty, unvindicated little emotions." In Europe all that's "low" in human beings is considered important, and "that is called art and with that art one is supposed to lessen one's thirst." 13

So difficult, complicated, heterogeneous, highly stratified, Freudian Europe was replaced by the primitive simplicity with which the romantic elite of the turn of the century regarded peasants. It was the kind of elitist simplicity which characterized the German nineteenth-century scholars who spoke of the folk-character and taught "Volkerpsychologie" in which, for example, anthropologist Franz Boas had taken courses. It was not an unsympathetic kind of elitism: devoid of racism it sees people as natives in their own right. But natives they are, primitive and in their primitiveness all equal. Or, as Goldschmidt writes about Boas: "It was as if his belief that all people were equal rendered them all the same."14 And Franz Boas in our context is an important man.

Franz Boas, the godfather of modern American anthropology, is a German Jew who left his fatherland and came to America. In Germany he experienced the rise of antisemitism. It marked him. In America he takes an active part in the struggle against racism. But that is only one of his manyfold activities. America in the period between the two world wars is a fast-changing country. Not all the changes are for the good, but there is hope. In the immediate post-World War I period-the Progressive era-a wave of optimism sweeps America; social change seems possible, even probable. But change is more difficult than people think. The optimism wanes; in the nurture-nature debate which is the permanent debate of the twentieth century, the nature side is winning. Eugenics becomes popular. But Boas and his students are firmly on the nurture side. Anthropology will set the human mind free; comparison with other cultures will teach America that values are relative and that many problems are of social, not of biological origin. The next step is to state that anthropology must be instrumental for social change in America. It is, among others, Ruth Benedict, Mead's guru, teacher, friend, and lover, who takes this step. She is not the only one: "With objectivity, particularity, and an operational approach, social scientists in the 1920's felt confident they would succeed where political Progressives had failed," writes Margaret Caffrey in her biography of Benedict. ${ }^{15}$ Social scientists expect that anthropological findings about the way other societies control and manipulate life will give new impulses to America on how to manipulate and control itself. But this is only possible if the anthropologist leaves his prejudices at home when he goes into the field-no moral frowning upon promiscuous Samoans, but objectivity. That objectivity is a human possibility, they don't doubt. ${ }^{16}$

It is in this atmosphere that Boas raises the issue of puberty. Is this adolescent storm and stress, this nail biting and grudging revolt, this burning sexual desire and sudden

\footnotetext{
${ }^{13}$ Spies, Schönheit und Reichtum, pp. 392 ff.

${ }^{14}$ Introduction in: The Anthropology of Franz Boas, Essays on the Centennial of His Birth, ed. W. Goldschmidt (San Francisco: Howard Chandler \& The American Anthropological Association, 1959).

${ }^{15}$ Margaret M. Caffrey, Stranger in This Land (Austin: University of Texas Press, 1989), p. 121.

16Ibid., pp. $118 \mathrm{ff}$.
} 
shyness really necessary? If there is somewhere on earth a society where a straight way leads from childhood to adulthood without a detour along the road of storm and stress, worried America should learn from that society. Or as Franz Boas writes in the Introduction to Coming of Age in Samoa:

In our own civilisation the individual is beset with difficulties which we are likely to ascribe to fundamental human traits. When we speak about the difficulties of childhood and adolescence, we are thinking of them as unavoidable periods of adjustment through which every one has to pass. The whole psycho-analytical approach is largely based on this supposition.

The anthropologist doubts the correctness of these views, but up to this time hardly any one has taken the pains to identify himself sufficiently with a primitive population to obtain an insight in these problems. ${ }^{17}$

Margaret Mead does. In the mid-1920s she goes, twenty-three years old, to Samoabecause Boas wants her to study adolescence and because she herself wants to do that in Polynesia. It is a tremendous adventure for an anthropologist; fieldwork in anthropology, apart from Malinowski's, is fairly rare. Fieldwork by a young woman, about sex, on an exotic island, is of course a dazzling novelty. And the results look as if there is a message for America in them: it is not by accident that Coming of Age is subtitled A Psychological Study of Primitive Youth for Western Civilisation. The last, long chapter of Coming of Age in Samoa is devoted to adolescence in America and how to soften this painful period. Samoa has shown that it can be done. But has Samoa shown that?

In Samoa, in the part that is colonized by America, Margaret Mead installs herself on the back porch of a Navy medical dispensary manned by a white couple. It is, she assures the reader of Coming of Age, an "absolutely essential neutral base."18 On this back porch she receives her main informants: young girls. They giggle and always give for an answer: "I don't know." 19 But Mead, more than once and probably correctly accused of bullying her informants, forbids this nonsense: she wants straight answers. She gets them, because as $\mathrm{H}$. Schulte Nordholt has so nicely put it: power breeds knowledge. ${ }^{20}$ She is not surprised that the answers are so much alike: "in a closed and well-studied community," she later writes, "every item of information about one individual is also information on every individual in the group." 21 But according to this law, in the wellstudied Samoan society Mead is also very well studied-by the girls who are her informants and who communicate to each other what the white lady wants to hear. Because, with a variation on her own quote: "every item of information about the researcher from one informant is also information about the desired behavior of other informants." Or in simpler terms: of course these girls gossip for hours about the strange woman who presses them to confess that they have lovers. Well, they have lovers if she wishes so. Mead is content. Altogether it has taken her only nine months to learn the language and do the fieldwork. After this period she goes home and writes the bestseller, Coming of Age in Samoa. In Samoa, she writes, "sex is a natural, pleasurable thing; the

\footnotetext{
${ }^{17}$ Franz Boas in his foreword to Margaret Mead, Coming of Age in Samoa, a Psychological Study of Primitive Youth for Western Civilization (New York: Blue Ribbon Books, 1928), pp. xiv-xv.

${ }^{18}$ Ibid., p. vii.

${ }^{19}$ Ibid., p. 123.

${ }^{20} \mathrm{H}$. Schulte Nordholt, Bali: Colonial Conceptions and Political Change 1700-1940, from Shifting Hierarchies to Fixed Order (Rotterdam: Comparative Asian Studies Program, 1986), p. 27.

${ }^{21}$ Mead in Anthropology of Franz Boas, ed. Goldschmidt, p. 32.
} 
freedom with which it may be indulged in is limited by just one consideration, social status." Not only the young are sexually free-adultery is tolerated as well. It relieves the strain of married life, as escape relieves the strain for the young: the extended family and the households of relatives always give shelter to children and young people who run away from pressure at home. And Mead concludes: "Among the factors in the Samoan scheme of life which are influential in producing stable, well-adjusted, robust individuals, the organisation of the family and the attitude towards sex are undoubtedly the most important." But knowing this, "we have not finished with the problem. A further question presents itself," she writes. The question is about America, and the reader must ask himself: "If it is proved that adolescence is not necessarily a specially difficult period in a girl's life-and proved it is if we can find any society in which that is so-then what accounts for the presence of storm and stress in American adolescents?" Sexual restrictions and feelings of guilt, she answers herself. And offers the solution: "The present problem of the sex experimentation of young people would be greatly simplified if it were conceived of as experimentation instead of as rebellion, if no Puritan self-accusations vexed their consciences." 22 Sixty years later Derek Freeman makes plausible that Mead was fooled-by the adolescent girls who were her most important informants, by herself, or by both. Life in Samoa, especially for young girls, doesn't seem to be so permissive, neither now nor in the 1920s. And the mental health of the "stable, welladjusted, robust" Samoans is as dubious as ours is. ${ }^{23}$

The Samoan experience is repeated in Bali: a hypothesis based on the social worries of America is formulated. The benefits of the research are for America too-not for the natives of the studied community. About those the Boasian anthropology is remarkably unsentimental, with a "curious detachment which is slightly repellent to social scientists who are absorbed in people," as Marian Smith writes in an essay about Boasian anthropology. In spite of the reputation of progressive thinking within America, in the field the Boasian anthropologists are interested only in "the traditional, the customary, the normative," as Goldschmidt wrote in 1959. That prevents participation, and so the anthropologist, thinking that everybody "in a society must be thinking and generally behaving in ways appropriate to that society," doesn't develop a sixth sense for "interaction among individuals, loving and hating, manipulating and conniving." The result is: "The study of the rules of the game, not of the game itself." 24 In itself a dubious affair, the studying of the game is all the more fruitless if the rules are not understood to have been laid down by colonial governments.

In a way the Boasian anthropologists are the opposite of those anthropologists today who go to the Third World to change the fates of the natives. And yet they are alike: both reckon that they will have political influence at home. Both suffer from wishful thinking. Both sympathize too easily with political ideologies which change countries in police-states. In the case of Boasian anthropology this means that people are not seen as (a) colonized and (b) peasants. They are seen as apolitical primitives. Colonialism, Boas' students think, changes primitive people only at the fringe. The real thing is still there, preserved, although under attack from something other than colonialism: modern civilization-whatever form that may take. Colonialism is not synonymous with this

\footnotetext{
${ }^{22}$ Mead, Coming of Age in Samoa, pp. 201, 223, 197, 242.

${ }^{23}$ Derek Freedman, Margaret Mead and Samoa, the Making and Unmaking of an Anthropological Myth (Cambridge, Mass.: Harvard University Press, 1983).

${ }^{24}$ Anthropology of Franz Boas, ed. Goldschmidt, pp. 58, 2, 38, 3, 3.
} 
"modern civilization"-colonialism is not bad. Modern civilization is. It is the great destroyer of old cultures. Luckily the anthropologist is just in time to describe those cultures before they go under. And so he is not interested in processes of change, or interested in people's desire for change. He is interested in "his" people as an unchanged people. He is focused on what is "left," and, of course, he starts to regret change when he sees it, because change is not in his interest. And often he doesn't see how far change is already under way, because he wishfully thinks that he is describing the "real thing," the real structure under the superficial layer of colonial, missionary, or technological influences. And so he develops no sixth sense for political unrest. That makes it possible that in the abundant descriptions of Bali by amateur or professional anthropologists we read a lot about the training of a little legong dancer, but we never read that behind the Bali Hotel the natives have built one of their own, independent unsubsidized "wild schools" with five hundred tuition-paying pupils and idealistic nationalist teachers, who teachas on Java-a revolutionary curriculum aimed at independence. No wonder older educated Balinese nowadays declare prewar anthropologists basically tourists who wanted a carefree life. And they know about tourists; they have seen them increasing in number and in vulgarity. Like many popular tourist resorts it is popularized by artists.

In the mid-1930s Bali is absolutely "with it." Expensive travel agents sell trips to the little island. It is a resort for the jet set; in the mid-1930s about 30,000 tourists a year visit the island. They love it. And that is understandable. Bali, 38,000 square miles and one million inhabitants, with its beautiful partly animistic, Bali-Hindu culture, its lovely rice-fields, its modern comfort of asphalt roads, and its absence of colonial agribusiness is a delight. All the people who really matter have been there-from Cole Porter to Lord Mountbatten. Spies has shown them around, of course. The photo books of Krause, doctor and photographer during the 1910s in Bali, have prepared them for the pleasant shock of beautiful nude girls and charming little boys. It doesn't take long before the dirty-postcard industry has reached the island. The Balinese seem willing models; the books, but especially the more daring postcards, take their place in the colonial tradition of the pornographic cabinet-photo. ${ }^{25}$

Some of the tourists come for the beauty of the island. Others come for sex. Bali has the reputation that the girls are easy-going and the boys willing. In a sad way Bali is becoming for the 1930s what spoiled syphilis-infested Tahiti was for the 1920s. But not everybody finds that so sad. Margaret Mead makes the comparison too, and she very much approves of "Tahitis" and "Balis," not because she approves the vulgarization of life, but because these islands are so useful an example for the Westerner: "In a good and very important sense the ways of life of simpler and different peoples can serve as symbols for the nostalgia or the dreams of civilized spectators; they can mobilize longings, sharpen social perceptions, crystallize attitudes toward change," she writes. And she continues:

The French academician reading a Jesuit missionary's account of the Red Indians, the English theorist enchanted with Captain Cook's voyages, the American schoolteacher or stockbroker fascinated by Frederick $O^{\prime} B$ rien or James Norman Hall-all seize upon something in these accounts which has symbolic reality for them and for their periods.

It has twice been my accidental fortune to make ethnological expeditions to islands which, besides presenting an ideal setting in which to investigate certain

${ }^{25}$ Toekang Potret, 100 jaar fotografie in Nederlands-Indië (1839-1939) (Amsterdam: Fragment, 1989). 
theoretical problems of the relationship between heredity and environment, have also been current daydreams in the Western world-the South Sea Islands in 1925, and Bali in 1935. In both instances, the announcement of my destination to a group of listeners at home caused the same breathless stir, as if I had said I was setting off for heaven. People crowded in as if to touch me; others moved a little away, as from one already set apart for more than earthly delights. From their longing "Oh, take us with you!" to their fervid "Oh, tell us what it was like!" the daydreams of the two periods were registered, accurately and sensitively, as by a needle moving on a smoked drum.

These daydreams were essentially different, and the difference reveals, I think, a significant and hopeful change from the outlook of the 1920s to the outlook of the 1930s. In the 1920s there were people who wanted to go to the South Sea Islands as a personal escape from their postwar world, from a dull and empty routine, from the denial of spontaneity, and the trammeling of individual passions. They wanted to escape to a kind of divine nothingness in which life would be reduced to the simplest physical terms, to sunshine and the moving shadows of palm trees, to bronzebodied girls and bronze-bodied boys, food for the asking, no work to do, no obligations to meet. They wanted to go to the South Sea Islands and never come back ... the divine, sensuous inactivity was too alluring.

The steamship companies which advertised Bali, in the 1930s tried to make Bali the lineal descendant of the Tahiti of the romantic 1920s, with the slim figure of a high-breasted scantily clothed girl as the symbol. But they failed. The average tourist-the businessman from Milwaukee, the college boy from California, the schoolmistress from New England-came away from Bali talking not of undressed maidens but of happiness and art. They asked in wonder "What makes the Balinese so contented?" They did not, like the escapist, moan, "Oh, why can't I live here forever?" For even the cursory three-day tourist visiting the Dutch East Indies in the 1930s recognized in Bali the very opposite of the pleasant, sensuous idling away of life which the romancers had imputed to the South Sea Islands. ${ }^{26}$

She then sketches Bali as an unstratified, but yet a complex or, in the jargon of her time, "highly patterned" society with highly happy people-so that does away with the idea of the 1920s that happiness and complexity don't go together. On the contrary. Look for example at the Lepchas-a simple, contented people, but dull! That doesn't mean, of course, that complexity in itself is a source of happiness. America proves that it is not:

We in America and in Europe have followed neither the simple ways of the Lepchas nor the complex ways of the Balinese. More and more children have grown up, insecure and frightened, clutching at any support, frustrated and embittered, until symbols of power and conquest and destruction have become frighteningly congruent with their needs. Totalitarian states have capitalized on these needs, have built symbols so relevant that they have been able to turn out armies of youth marching willingly to destroy and be destroyed. Today, even the Balinese on their little island, with their good society, are no longer safe; their rajă putri, their white queen under whose rule their way of life was respected and conserved, is in exile. Tomorrow destruction may come to their terraced green valleys which yielded food enough for all, just as destruction has come to so many small countries, each in its own terms seeking for the good society.

26Margaret Mead, "The Arts in Bali,"in Traditional Balinese Culture, ed. Jane Belo (New York: Columbia University Press, 1970), pp. 331-33. 
Many Americans in the 1920s sought for an escape as single individuals from a society which denied them self-expression. Many in the 1930 s sought for a formula by which we could build our society into a form which would make possible, on a firm economic base, both simple happiness and complexity of spiritual expression. Of such a dream, Bali was a fitting symbol. ${ }^{27}$

So people as fitting symbol are happy, no, are obliged to be happy to fulfill the Western need of daydreams. Yet there are people who doubt whether daydream-Bali exists. Mead and Bateson may think so (Bateson even writes that the Balinese are so rich that they waste rice), but in fact there are parts of the island where people live off sweet potatoes and maize. Does the "firm economic base" Mead's Bali is supposed to have, really exist? Critical Dutch comment upon the actual misery and poverty of the people in the east and the north, the new rigidity to which the Hindu caste-system in Bali has developed under colonial rule, the high taxes which the Dutch-Indies Government imposes on poor people, the stunting wealth of the Rajas who are the highest native civil servants as well, the appalling housing of the poor, the syphilis and the tuberculosis. the exploitation of the women, the labor of children from the age of four, the opium-addiction which increases as the Government opens more and more profitable opium-dens, the compulsory labor for Government projects, the unspeakable dirt, the concentration of the culture in the southern areas where life becomes richer and the disappearance of culture from the villages where life becomes poorer, the obligatory character of Balinese culture in public life, and the restrictions of freedom of speech and union. "Please, stop embellishing Bali for the tourists," writes Korn, a jurist who lives in Bali and has a commission from the Government to do research on Balinese adat. ${ }^{28}$ In his voluminous study Adatrecht van Bali he complains about the misery of tuberculosis and poverty and the costs of the (literal) facades of temples along the asphalt roads which are built for the official visit of the Governor-General in 1937. Bali's glamor turns itself against the island, he remarks.

Other critics, among whom the renowned Dutch Protestant minister and theologian Dr. Kraemer ridicules the colonial concern with Balinese culture, call Bali an artificial, would-be authentic tourist place, a fenced garden, a cultural reservation, an open-air museum. ${ }^{29}$ The so-called authenticity of Bali is seriously attacked by the Christian author Mary Pos, who in 1940 writes sarcastically about the veneration the white residents in Bali pretend to have for Balinese tradition. Meanwhile, she writes, the white resident drives in an open convertible with a bunch of lover-boys on front seat, back seat, and hood. And those same white residents, she remarks, complain that missionaries will spoil authentic Bali! ${ }^{30}$

All these critics find fierce enemies in the Bali-lobby of scholars and politicians who declare the Balinese, as Rouffaer did, "the best in the entire archipelago." Poor Bali is destined to be the pearl in the crown of Queen Wilhelmina, the diamond in the proverbial girdle of emeralds. And it is not going to be spoiled by missionaries. When in the 1930 s missions want to come in, the Bali-lobby closes its ranks.

An important representative of the Bali-lobby, which counts Korn and Bosch and Lekkerkerker (who has succeeded Rouffaer as the director of the Bali Instituut) among

\footnotetext{
27 Ibid., p. 340.

${ }^{28}$ V. Korn, Het Adatrecht van Bali (The Hague: Naeff, 1932), pp. 337-40.

${ }^{29} \mathrm{H}$. Kraemer, De strijd over Bali en de zending (Amsterdam: Paris, 1933), pp. 32, 56, $130 \mathrm{ff}$.
} 
its members, is Dr. Goris. And Walter Spies, although not a friend of Goris, is not a friend of intruders either. Goris and Spies, for both of whom Bali is a heaven of tolerance in an anti-homosexual world, stand for everything traditional in Bali if only it is a fitting symbol of Western daydreams. Change will spoil the island, which, of course, in the long run is doomed to be spoiled. In Mead's words: "There is not much hope for Bali ultimately because their social system is founded on religion and that is bound to crack before the Muslims, the Christians or the modern sceptics who worship industrialism." 31 For the Bali-lobby, tolerance of religion in Bali means not only the penetration of Christendom but also of despised Moslem ideas. And Moslem ideas, in their turn, stand for Java, which means: ideas about the modernization of native society; political emancipatory ideals; printing newspapers in what are for most Westerners incomprehensible indigenous languages like Malay; trade unions, protest against compulsory labor; "wild" schools; learning English; wearing shorts and trousers; watching movies; and-God forbid-nationalist propaganda. ${ }^{32}$ The foreign residents in Bali are as a rule opposed to nationalism as well as to the missions; the influential Covarrubias expresses in his book desire for a natural Bali. Dr. Goris, who is a Government adviser, warns his countrymen against missionary influences that will de-Balinize Bali and will open, in the name of the freedom of religion, the island for Islam. Already Boedi Otomo, the union of emancipating pro-Western Javanese priyayi, has reached Bali. The Government has wisely forbidden it. Balinese culture, though ages old, is too fragile to endure the Javanese infiltration. If Bali has to be modernized, the Government will set the pace. Not the natives. ${ }^{33}$

And, of course, Bali is modernized. The infrastructure of its two most renowned native institutions is so drastically changed that in some respects only a Balinese facade is left. These institutions are the village and the irrigation system, praised till today as symbols of Balinese self-sufficient democracy on the village level and models of cooperation. But, in fact, they have been remodeled and governed by the central administration since the occupation by the colonials in 1906, just as engineers trained in the Netherlands have traded the old indigenous dams and bridges for concrete ones. Not a bad move as far as agriculture is concerned. But a fatal blow for authenticity. The function of Raja, former lord of the water supply, is in the new infrastructure replaced by a big tap. An adat in which secular and religious administration is indistinguishably intertwined is traded for secular control of the water supply and water distribution. Yet on the surface everything remains the same: the water thieves keep stealing water and the village-based irrigation-union assembles to "distribute" water among the members, and to play out their traditional intrigues. But the colonials are in control. To a foreigner the difference is nearly invisible. The colonial myths about the autonomous village-republic are so convincing-as convincing as the image of the Rajas as tyrannical, superfluous imposters from Java. In fact they are neither imposters, nor from Java, nor superfluous. If there is anyone intruding into Balinese society from Java, it is the Dutch civil servant who carries out the instructions from a central Government in Batavia, that, in the words of Van Heutsz, "wants to change all this," meaning traditional Bali. "All this" consists principally of the intertwining of religious hierarchy with culture and administration. These ties are loosened. Colonial Bali makes a difference between religious and

\footnotetext{
30Pos, Werkelijkheid op Bali, pp. 69-70.

${ }^{31}$ Mead, Letters from the Field, p. 172.

${ }^{32}$ Schulte Nordholt, Bali: Colonial Conceptions, pp. 36-47.

${ }^{33}$ R. Goris, De strijd over Bali en de zending (Batavia z.j.), pp. 1-34.
} 
political affairs. To legitimize that, history has to be rewritten. And it is rewritten, stressing the value of Dutch insight into Balinese history. ${ }^{34}$ The job is done so effectively that Mead decides to skip the knowledge to be retrieved from Balinese sources: after consultations with her Dutch coaches she decides that "it seems very clear that in Bali literature has served primarily to paralyze thought and to give everyone a sense of intellectual inferiority." 35

The rewriting of Balinese history is not entirely an academic affair. It has a practical implication: if Bali is to remain Bali in the way the colonials perceive it, it needs constant care. In fact-it has permanently to be redone, to be embellished. This "embellishment" which irritates Korn so much, is the core of the Government's cultural policy. And the team leaders are Dutch. So, for example, after the earthquake of 1916 the Government sends a Dutch architect to direct the rebuilding and restoration of the Balinese temples because, as a renowned colonial author puts it: Balinese are not good at (re)building temples. They need the Dutch to hurry things up a bit. And to do things thoroughly-the way the Dutch are thorough-replacing, metaphorically speaking, sandstone with concrete. ${ }^{36}$ Yet, despite Dutch pride in Balinese restoration, the peasants complain: "Yes, the temples are beautiful, but the stomachs are empty," they comment to Korn. ${ }^{37}$

The Dutch don't limit themselves to technical assistance: the Balinese need the Dutch also to guide their sense of beauty. Because Balinese take a lot of liberties with their cultural inheritance which they seem to regard not as an inheritance but as a living culture. Dutch intervention is a necessity. For example: Balinese sculpture on their temples modern images of a man on a bike, a colonial soldier with a helmet, or a colonial civil servant with a hat. Any responsible colonial civil servant in Bali, with or without a hat, knows that he has the duty to prevent or repair this kind of cultural rampage: Balinese temples have to remain Balinese, or to become even more Balinese than they were. Walter Spies shares this view: "For us, the race that has a cultural mission, and is in possession of a historical survey of the development and the decline of so many different races and their folk-art, it is a duty to warn against deformation of the folk-arts, and against the destructive consequences of a fancy for fashionable whims and the blind aping of not fully understood expressions of arts of other races." ${ }^{\prime 38}$

So the Balinese need Western guides to teach them how to remain authentic Balinese. Spies is one of these: he assists in creating dances which are to be performed for tourists on the grounds of the KPM-owned Bali hotel. He wants the dances to be real Balinese, and yet harmless to the Western eye that is not used to the outlets of ritual "violence" so characteristic of trance-dances.

In the same way as Spies wants to direct the adaptation of Balinese to modern life, the colonial Government adapts the Balinese caste system to the needs of the modern bureaucracy. It does it with the thoroughness which, according to Furnivall, is characteristic of Dutch colonial rule. An office is set up for the registration of the caste member-

\footnotetext{
${ }^{34}$ Schulte Nordholt, Bali: Colonial Conceptions, pp. 5, 11, 21, $27 \mathrm{ff}$.

${ }^{35}$ Mead, Letters from the Field, p. 214.

${ }^{36}$ Marie van Zeggelen, Bali (Amsterdam: Scheltema \& Holkema's, 1931), pp. 22 ff.

${ }^{37}$ Korn, Adatrecht, pp. 337, 340.

${ }^{38}$ Henk Schulte Nordholt, "Stenen vreemdelingen op Bali," Orion [Franeker, The Netherlands] (DecemberJanuary 1986-1987), p. 8.
} 
ship of every Balinese. Soon it becomes clear that it is rewarding to be of high caste; it provides, for example, exemption from compulsory labor. So, many falsify their genealogy. The successful falsifications and the exemption create bitterness among low-caste Balinese. Bitterness too is caused by the increasing colonial control over attempts to change caste by marriage. Colonials don't favor change of caste, as they disapprove of any kind of dynamics in Balinese society which they have not fostered themselves. They cherish adat, and, with the change of the Ethical Policy around 1920 from a peasantoriented policy to a priyayi-oriented policy, they restore the Balinese Rajas to their titles. They are now called "Zelf-Bestuurders" (Self-Rulers). In fact they are strictly controlled civil servants. They seem to be in charge of their people; in fact they are not. So SelfRule is a facade. But yet-once installed, the Self-Rulers are invulnerable. The Dutch can't dismiss someone whom they have recognized as being by birthright their highest civil servant. That would undermine their own policy of restoring the ancient hierarchy in the Dutch-Indies as the cloak under which the Dutch themselves find cover in this period of increasing native criticism of colonialism. So the Rajas are free to do as they like. And some like to cheat their people, and in fact force people to whom they lend money to mortgage their land to them. The seed of the terror in Bali in 1965, when people kill each other in decades-old conflicts over land, is partly sown in these years. Self-Rule may be a farce, but for the poor it is an expensive farce.

The Balinese, at least the educated Balinese, are aware of the colonial strategies behind the manifested love for their Rajas. It is part of the remaking of Bali. Of the Balinization of Bali. ${ }^{39}$

The Balinization of Bali is a political concept which, fifty years later, is remembered well. Educated people react spontaneously to the term: "Balinization is this: the Dutch wanted us to be a living museum," says the Balinese historian Prof. Dr. Ide Gde Ing. Bagus. He recalls his primary school: it was built in temple-style. The designer was $\mathrm{H}$. Te Flierhaar, a former Dutch teacher who became a civil servant assigned to the Balinization program and was assisted by Spies in designing Balinized buildings. ${ }^{40}$ Bagus: "Te Flierhaar is the embodiment of the Balinization-philosophy. Balinization means for us: conservative educational policy. Bali is not allowed to be modern, it is not supposed to be touched by new ideas. The Dutch tell us: education is all right, but it must be blended by tradition. For example: when I am in the primary school, I have to dance in the Balinese way. I have to draw in the Balinese style. I have to do Balinese literature. They don't want us to be modern, because that is Western. But we see modernization not as something Eastern or Western. It is the application of science, rationalism. But it is not allowed. We have to be Balinized."

Mr. Wijakusuma, a leading fighter in the Indonesian Revolution, and like many educated Balinese an experienced reader of Mead, Covarrubias, Belo, and others, also remembers Balinization very well: "I already heard about Balinization when I was a child. But they didn't succeed, did they! As an ideology it disappeared after the war. But it is the Westerner who wants to Balinize us, and his intention is, in fact, that for him Bali is a paradise. But with the common people Balinization doesn't succeed. The common people have other things to worry about. And conflicts. Always conflicts. About what? About the issues the conflicts nowadays too are about: water, land, caste, and

\footnotetext{
${ }^{39}$ Schulte-Nordholt, Bali: Colonial Conceptions, pp. $34 \mathrm{ff} ., 28 \mathrm{ff}$.

${ }^{40} \mathrm{H}$. te Flierhaar, De aanpassing van het inlandsch onderwijs in Bali aan de eigen sfeer (Brochure Oegstgeest: Hendrik Kraemer Bibliotheek s.a.).
} 
women. And inheritances, of course. Ah, if all these people who came here between 1930 and 1940 had given our island one good thought, they could have seen how life was changing. But, it is true, in those years it was not yet obvious. We already wanted during that time Western science, because we need Western science. For our art too. We love our fine arts and we keep to our own culture. But the Western scholars teach us how to understand better the relation between our music and our dances, and our orchestras and dances have improved much compared with the time of the Balinization."

Probably the sharpest anthropological mind of the island, I Made Kaler, was in the 1930s the secretary, guide, informant, and interpreter of Mead and Bateson. He too remembers" the Balinization policy well: "The intention was to keep us from changing and to lead Bali back to the dark ages (jaman kuno). Everybody I knew hated it. The people who did approve were the Balinese who licked the ass of the Dutch, in particular the people of high caste who were privileged by the Dutch."

Ibu Yasmin Oka agrees with I Made Kaler. Before the war she was a teacher at the only high school there was in Bali: a school that taught housekeeping to girls. "Balinization is to discourage us from learning things," she says. "It goes on till the Japanese invasion. During these years of the Balinization-policy, we always wonder: why has Bali to remain static? Why don't we change when times change? In 1939 for example a 'huishoudschool' [school of housecraft] is built in Denpasar. The design is an idea of Te Flierhaar. There is a main building where the theory lessons take place and an annex for the lessons in, for example, cooking. The kitchen is in the annex-it was so impractical. But Te Flierhaar found that truly Balinese, because in his compound the Balinese servant did the cooking in a small annex. And at that moment we understood what Balinization means: we, the teachers and the girls, had to go from the main building to the annex through the open air, even when it rains. Te Flierhaar tells us to hold a palm leaf above our heads when it rains because in his eyes that is typical Balinese. Later we get a kind of roof over that gangway from the main building to the annex, but in fact that was not permitted."

So Balinization was for Ibu Yasmin Oka humiliating, because its principle, as she understood it, was that all Balinese should not only be old-fashioned, but behave like servants who cook in annexes. But she was not a servant-she had gone to school in Java, she was a teacher. So she waited for Merdeka.

After Merdeka we do away with Balinization. We practice Balinization, but in a completely different way. Not to keep people dumb. What we do away with, for example, is that marriage of a boy of lower caste with a girl of higher caste is not permitted by the Dutch if the parents of the girl object to that marriage. In general, what was traditionally not useful, we did away with. For example, after the war Dr. I Gusti Made Tamba comes to me and asks me what I think about the haircuts of our schoolgirls. Because they are modern, these girls after the war! They cut their hair! But I don't give Dr. I Gusti Made Tamba an answer. Because I have two daughters myself, and maybe they are going to protest against what I say. And I think to myself when you wear your hair short and you want to wear the traditional Balinese dress for the occasion of a party or a ceremony, you yet can make the traditional chignon, so I teach the girls at school how to use a chignon of artificial hair.

I was very young when already I had that nationalist feeling that Balinization was no good, even though I am not a politically talented person. There were in those years before the war two mainstreams: nationalism and Balinization. Sure, there are 
Balinese intellectuals who before the war were pro-Balinization, like the uncle of my husband who is a tjokorda [a high-caste official]. But personally, I was not pro-Balinization. I see all around me such a lot of discrimination.

The discrimination she refers to is that within Balinese society where caste is a central issue. As a person without caste, married to a Brahman, she feels deeply about casteproblems. And she repeats: "Always there are caste-problems in Bali! In that period more than ever. Now it is decreasing a little. When a Brahman girl comes up with a jaba [a person without caste], the parents of that girl go to the Dutch civil servant. And he says: this marriage will not take place."

Part of the Balinization of Bali is the intruding of the colonials in the sexual life of the natives. The colonial idea about the natives is that they practice free love before marriage and don't mind being seen nude. I Made Kaler, Mead's secretary, having read a great deal about Bali in the colonial times, still wonders where the Dutch got the idea that the Balinese have no adat on sex, shame, and nudity. He has bad memories about the sexual relations of white people and Balinese, and remembers in particular "the Dutch civil servants and the foreigners exploiting small boys." $\mathrm{He}$ also remembers being disgusted at the general ideal of the colonizer that in Bali all sexual behavior is tolerated. One of his bad experiences in this field is with the KPM officials for whom he works as a guide after the departure of Mead and Bateson in 1938. Intending to do cultural tours with foreigners, he is forced to find prostitutes for the tourists. When he refuses, the tourists object to KPM and he is dismissed. During that period he also objects strongly to the Balinese models posing nude for painters and photographers, but he knows he will not win: conventional colonial scholarship dictates that the Balinese feel no shame at being naked. Nudity belongs to the colonial image of Bali which is commercially exploited. The Balinese, says I Made Kaler, know about that, and have the feeling that the Government approves: "That's why," he says, "the people don't want to sit nude and are angry when they were forced to do so, but yet agree. They are afraid to be arrested if they refuse."

The anger expresses itself in 1940 when the Parindra in the Bali Congress support a resolution asking the Government to forbid the use of nude women and children as models. ${ }^{41}$ Nude photography, says the resolution, "is an offense to the people." And these offenses were indeed quite openly given: the author and photographer Hickman Powell, for example, writes in his popular book Bali, the Last Paradise about his own treatment of the natives: he has an old Balinese servant ("old hag") who is angry with him because he has girls sitting nude in his atelier for his artist friends. He dismisses her, and within a few hours he is bombarded by applicants for the job. He chooses a girl who wants to do the housework and the sitting as well. And he knows why she consents: she has to eat, he admits, unashamed.42 Powell has friends who share his ways: Andre Roosevelt produces in the 1930s a sexy movie about Bali. The movie, objects Covarrubias, has made Bali "New Yorkese for Sex-allure." ${ }^{\text {" } 33}$

Of all this, says Wijakusuma, politically minded people like himself were aware in the 1930s: "The European who comes here, says: Bali is a paradise. Yes, I answer, but for whom? They say: Bali has enough rice, so it's a paradise. Aah, in fact it is all very simple.

\footnotetext{
${ }^{41}$ Interview with I Made Kaler, June 6, 1986, Denpasar, Bali.

42Powell, Last Paradise, pp. 150-51; Howard, Margaret Mead, p. 200.

${ }^{43}$ M.Covarrubias, Island of Bali (London: KPI, 1986; orig. 1937), pp. 391-92.
} 
These learned Europeans mean another paradise than we do. For us Bali is the place where everything is holy-we pray to the gods, as well as to the plants, the animals, the flowers. That's our religion. But for them Bali is a paradise because they have a beautiful house, many servants, beautiful gamelan, a lot of food. And they have the girls with the bare breasts. But I can tell you-to a Balinese man bare breasts are nothing! They are only thirty percent! Erotic she is when completely nude! But for the Western man bare breasts already are a paradise. ... Aah, Balinese paradise doesn't exist behind the scenes. It exists in those years for certain people in certain functions, people who have a good status."

The white residents of the island are ignorant of these considerations of the natives. They are self-chosen exiles who have come to Bali for its "easy" sex, its beauty, its music, its art, and not for its problems. They paint or photograph, establish a hotel with an increase in not only sex-seeking but truly weird visitors who think Bali is the place to freak out. Many of the residents write a book or an article about their experiences, as a musicologist (Colin McPhee), a researcher (Belo), experts on art (Spies and De Zoete), as a dancer (Katharane Mershon), as a writer (Covarrubias), as a doctor and photographer (Krause), as a profiteer (Powell), as a hotelkeeper (Louis Koke), as a cinematographer (Roosevelt), or a political and erotic adventurer as the American woman who wrote her memoires under the Balinese pseudonym Ketut Tantri. Some of them have left us their letters, like those of Spies which are-except for the passages about his homosexual affairs-published. ${ }^{44}$

All these people live a comfortable life in unbelievably cheap Bali. They have numerous servants, own houses and cars. They command theater groups to play for them-the fee is a few dollars. Spies has a small amphitheater in his compound built for a birthday party, and while champagne is flowing he has two gamelan orchestras playing. His wit has not vanished under his riches: it is time I start to earn a little bit less money, he writes home. ${ }^{45}$ But, nevertheless, his col-

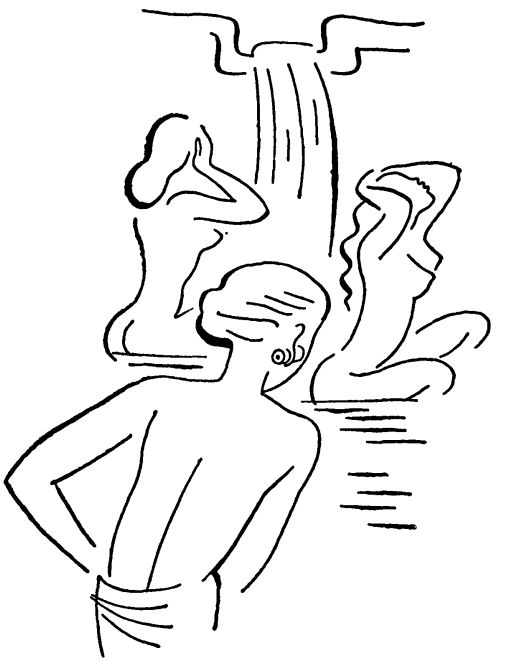
league Bonnet, the painter, is angry with him for his display of wealth. ${ }^{46}$ And Spies goes too far: he gets seriously in trouble when he starts renting out his house as a hostel; the behavior of the management, which Spies has handed over to two Germans, and that of the clientele is shocking to even the Dutch authorities 47 who by this time are used to, and sometimes involved in, a type of behavior which is quite uncommon in the DutchIndies civil service.

Yet in general the residents share the values of the civil servants. If they are critical, their criticism is superficial. It is Covarrubias who sets the standard of what is praiseworthy in the Dutch and what should be rejected. In his well-known and still reprinted book The Island of Bali he devotes two passages to colonialism. In the one he depicts the Dutch civil servants as rather pompous

\footnotetext{
${ }^{44}$ Interview with John Stowell, June 1987.

${ }^{45}$ Spies, Schönheit und Reichtum, p. 377.

46Interview with Ibu Gedong, May 1986.

${ }^{47}$ Rhodius and Darling, Walter Spies, p. 41.
} 
asses. In the other he congratulates the Balinese on their occupiers-if colonization is unavoidable, then the Dutch are the preferable colonizers; they preserve the Balinese way of life so beautifully. And he shows how beautiful "Europeans" like himself preserve the beauties of Bali: deploring vulgar tourism and praising the Balinese women for their chaste way of bathing, he prints one of his own drawings of a stark nude girl, bathing while on the edge of showing her vulva. This drawing of Covarrubias, a plain dishonesty to his text and the Balinese, is the type of illustration that in the prudish 1930s does sell well and attracts sex-starved Westerners to exotic isles. ${ }^{48} \mathrm{He}$ is praised for it by many. Mead is one of the people that admire him. She refers, like he does, to the legendary "numerous love-affairs" young Balinese girls have before marriage, love-affairs as unproven as those of the Samoan girls. ${ }^{49}$ As stereotypical as Covarrubias' views on Balinese sex, are his views on the history and sociology of Bali. All the colonial wisdom about age-old village-republics and unchanged irrigation-systems is there. And yet-it is understandable. One could live for years in Bali and easily misunderstand it.

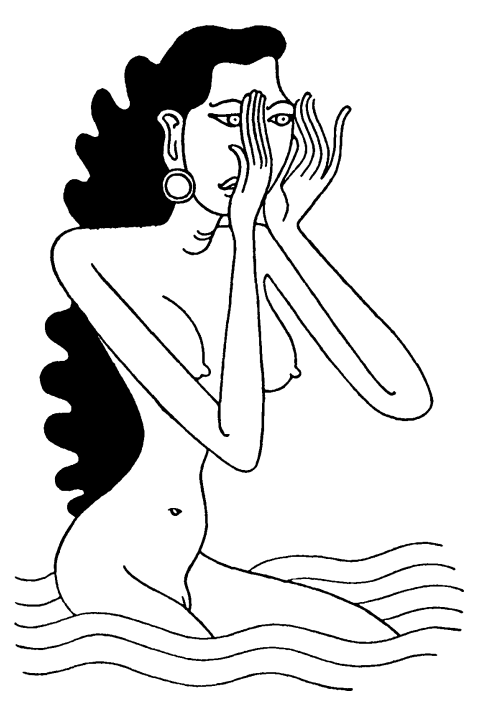

The main sources of information about Bali are the Balinese themselves. They areas we shall see-not talkative. The other sources are the Dutch civil servants. They are not naive. But they are not easily accessible to a foreigner. They know that they know too much to be able to give a favorable impression of the Dutch-Indies in the $1930 \mathrm{~s}^{50} \mathrm{Of}$ course they scrutinize phenomena like "wild schools" and of course they report to Batavia. They are constantly informed by the network of spies of the active Politieke Inlichtingen Dienst which is turning the Dutch-Indies into a police state. ForeignersSpies probably excluded-have not the faintest idea that this is what is happening. The natives of course know but they keep silent about it. Even to their own employers.

I Made Kaler, often praised by Mead and Bateson as their excellent right hand, was never open with them. He saw the gaps in their knowledge of Bali, but he didn't do anything about it. The reason, he says fifty years later, was not that he didn't like them. He did-they treated him as an equal, and were always friendly and polite. They taught him what books to read and why some anthropological techniques were better than others. And yet, he says, he couldn't be frank with them. They had set limits to what they wanted to know and that was all right with him; he had no intention of crossing his own lines; to be open with them was too dangerous. So they couldn't dream, he said, that, for example, he as a casteless person, a jaba, was oppressed. On the contrary, in Balinese Character Mead and Bateson stress that in fact the real victims of the caste system are those high up who suffer from the mocking, disrespectful behavior of the noncaste Balinese who form 94 percent of the population and against whom they are powerless. ${ }^{51}$ So the real victims of inequality in Bali are the people of caste-not exactly an

\footnotetext{
${ }^{48}$ Covarrubias, Island of Bali, pp. 403-4.

${ }^{49} \mathrm{Mead}$ is the author of the basic essay which forms the Introduction of Balinese Character.

${ }^{50}$ Schulte Nordholt, Bali: Colonial Conception, p. 41; Korn, Adatrecht, pp. 337-40.

${ }^{51}$ Schulte Nordholt, Bali: Colonial Conception, p. 10.
} 
analysis I Made Kaler would have agreed with. But he would, most probably, not have contradicted it either.

About what then did he talk with his employers? He informed them on culture and they worked on its psychological origins, and, as far as he was concerned, that was it. Of course he knew they thought Bali the "steady state" 52 par excellence. He didn't tell them that the "rust en orde" (the slogan of Dutch colonialism, meaning "calm and order") in Bali was not indigenous:

The rust en order in Bali made a deep impression on Margaret Mead and Gregory Bateson. They came from New Guinea where they had been carrying weapons. They had weapons with them when they arrived in Bali. But they didn't need them here. They never wondered what the reason was for all this calm and order. The reason was that all unrest and all criticism was effectively suppressed by the Dutch. But beneath this surface the feelings of bitterness among the Balinese prevailed. Bali was a sleeping tiger. The Balinese are not specially cruel or violent, but it is not surprising that the tiger woke up at last when the Dutch lost power. In particular during the period 1945-1950, and after the coup of 1965 much violence is committed by Balinese against Balinese. To Margaret Mead and Gregory Bateson I never talked about what was invisible, but very much alive in Bali. Talking was too dangerous, regarding the Dutch. Margaret Mead herself never broached a political discourse. The Dutch did give many privileges to the elite, to the caste-members-but that was an issue in which Mead and Bateson were not interested. Both of them had no affinity with politics. One time I asked Margaret Mead about the war of Japan with China. It had no significance, she said, it was just a rear-guard fight which would not spread over Asia. It seems to me that she also knew less about the political events in Europe than these Balinese who did read the newspapers.

I Made Kaler was not only one who was cautious in the company of "Europeans" as all white people in Bali were called. Ibu Gedong Bagus Oka, now a distinguished elderly lady, was in the colonial period a young teacher. She is the daughter of the secretary of the provincial council of Karangasem; her father, she says, was one of the first Balinese who spoke Dutch fluently. And she was one of the first Balinese girls who attended a training-college in Java. Her father was a prominent man, and he earned a salary of 150 Dutch florins a month. He knew precisely, because of his function, what a colonial Government was about, and how far-reaching Dutch power was. The police in Bali functioned very well, and had their spies everywhere among the indigenous colonial civil servants. Ibu Gedong:

Of course we wanted to be free. But we didn't tell. We were afraid. If you did say anything that made them suspicious, you were interrogated by the PID. You can't take any chance; it will cost you your job. The civil service paid well. That's why there was no corruption. The lower civil servant earned 30 Dutch florins a month, and on that salary you could live like a prince. Even for 7.50 Dutch florins an orderly could live well. If there was a place for an orderly, there were always many applicants. So the civil servant kept silent because of the salary and the interrogations.

I know how terrible interrogations are. I was interrogated as a young girl when I was in the training college in Java. An interrogation is terrifying, terrifying. And if it occurs more than once in your life you're sure to remain forever unemployed.

${ }^{52}$ G. Bateson, "The Value System of a Steady State," in Traditional Balinese Culture, ed. Jane Belo, pp. 384401. 
You're stigmatized. The PID came to our school and took me apart. They said: you've made the V-sign. I pretended to be ignorant about what a V-sign is. Ignorance is the weapon of the weak all over the world. But yet they interrogated me, about the Dutch national anthem, the "Wilhelmus," which had been sung at school. They asked me whether I had joined in singing it, or whether I had refused to sing it. I said: I sang the second stanza. I told them I didn't want to sing the first stanza with the text "Wilhelmus van Nassouwe ben ick van Duitsche bloet" ("Wilhelmus from Nassau I am, being German by blood"). The second stanza-In God I trust-that one I liked. I was very afraid of my interrogators.

One of the few other Dutch-trained female teachers on Bali was Ibu Yasmin Oka. Her husband, Idu Bagus Oka, now retired and a well-known connoisseur of Balinese dance, was in the colonial time a civil servant, a professional adviser to the farmers on such issues as new farming techniques and fertilizers. Both of them say: "In those days, then, we were silent about our resistance to the Government. The resistance in Bali was then only an affair of the intellectuals, that means the people who had been to high school or Mulo (the 4-year course after elementary school). But we were very careful, we concealed it. If you said one word in those days, you got sentenced, or they oppressed you in another way. When you read the books of the anthropologists of the prewar period, you see that they don't realize what was going on. They're only interested in culture, not in political relations." And Ibu Gedong adds: "Many of them visited my father when I was young. Margaret Mead, Gregory Bateson, Walter Spies, Katharane Mershon, Jane Belo, Colin McPhee, they all didn't come to Bali to render us a service. They came only in their own interest, and that means that they never integrated, never participated in our society. We as young girls imitated them: ooooh, Bali is so beautiful, Bali is such a paradise. We said that they had an illness: the Bali-itis. Look, they paid their interpreters and guides and informants, so these people confirmed everything their employers said. All these Europeans were frustrated Westerners who wanted to believe Bali was a paradise. It was their flight from the West which gave them this so-called insight."

I Made Tranta, now the owner of a chic antique shop, was in the 1930s the interpreter and the odd-job man of Jane Belo, Colin McPhee, and Covarrubias. He explains that foreigners in those days were politically myopic, and he wouldn't have dreamt of enlightening them:

To a Balinese every foreigner was equal to a Dutchman. To a Dutchman you never told what you really thought. Foreigners you treated the same way.

In the dessa the people were not yet so aware of politics. But in the city the people were. People in the city were against. Against colonialism. But that was not allowed. Like in the case of Budi Otomo, which was just an organization of young intellectuals emancipating themselves, the Dutch said: "This is Javanese influence. This must stop." The Dutch didn't like it when the Balinese learned political awareness from the Javanese. And the Dutch didn't approve of relations between foreigners and Balinese. Because relations imply discussions, and discussions could imply criticism of the Dutch. Foreigners too weren't allowed to express their political views; they couldn't even show interest in politics. Because they were always on a visa that had to be renewed, which always caused problems. I worked at that time for a English lady, Mrs. T. Pattinson. And she wrote in her diary things like: "The Dutch can't sit forever on their golden eggs." This diary was lying open on her desk, and I did read this phrase and I put the diary in a drawer. And I said to her: "This is very dangerous. Either you don't write these types of comments, or you keep your diary in 
your drawer. This is dangerous, for you and for me." You must understand that it was impossible to have any discourse with a Dutchman about politics. A foreigner wasn't even allowed to remark: well, colonialism, there are pro's and there are con's. That was already off limits. In that case your visa could be withdrawn and you had to leave immediately.

The Dutch police state was effective, so effective that the Indonesians got the reputation of being a "submissive" people. And Dutch, concluded Mead's guru, Ruth Benedict, were very good at ruling submissive people..$^{53}$

From "submissiveness" to "fitting symbol" is only one step, the step Mead made. And, as so often, she was right and wrong to make it. She was wrong as an anthropologist. But she was right as a public person. She knew that fitting symbols were what America wanted: "She did put Bali on the map," as David Stuart Fox says. She reinforced the paradise-like image that Covarrubias and Hickmann Powell and others had created. She didn't invent it. She timed it. And nobody contradicted her. Because she was not only a famous anthropologist, but she also was becoming an authority on America's spiritual needs, who answered, for example in her column in Redbook Magazine, with great certainty every question the general audience posed to her. Democracy, the role of parents in modern society, history as a medium of instruction in schools, laws to prevent war, the development of Indonesia, youth criminality-she didn't avoid any subject if asked a question about it. And people did ask her questions, because she had that unique quality of knowing what people craved: hope. She offered hope, out of conviction, habit, or a sense of duty. And out of self-confidence. When she was thirty-five she wrote about herself as having "a life-time of work behind me" (while her new husband Gregory has a "lifetime of work before him"). And her environment approved, at least in public, of her role as popularizer. Boas himself had preached that anthropologists had the task of popularizing their knowledge for the educated layman. He had done so himself, last time in his Anthropology and Modern Life, a book about contemporary social issues which for today's reader is still an example of decent and sensible writing. Benedict had written for the educated layman as well. But it is Mead who is perfectly fitted for the task. She is the great communicator. It doesn't improve her standards for scholarly work. The crisis becomes evident in 1934.

The year 1934 finds Mead together with Reo Fortune in New Guinea, where in the field they meet Gregory Bateson, just as isolated from scholarly company as they are. At first the three of them get on well. But tensions arise. The causes are twofold; Mead and Bateson fall in love. Fortune is jealous and there is nothing to distract him from his emotions. The second problem is Benedict's book Patterns of Culture which Mead and Fortune carry with them-in draft. The book which lays the foundation of the Culture and Personality school will turn out to be the most influential publication in anthropology in the 1930s. Mead, who is a disciple of Benedict, likes it enormously. Bateson shares her enthusiasm. Fortune doesn't. He has, apart from scholarly reasons, his own motive: he feels abused. Benedict has, with his permission, used his material on the Dobu and has, without permission, changed the interpretation of the material. He refrains more and more from the discussions between Mead and Bateson who-with Benedict's draft as a background-design the (scholarly) world anew. While planning how to reduce the description of the world to a few simple, all-embracing formulae the three of them get, each in his own way, overwrought. Or, as Mead later says about this period: "We were

${ }^{53}$ Caffrey, Stranger in This Land, p. 264. 
all understanding too much. Everything was too clear. It was the closest I've ever come to madness. It was a rigid, boxed drama." To which can be added Bateson's statement about their trio: "All three of us were pretty well psychotic." 54

It is the (inevitable) Jung who seems to restore the balance. Jung has written about mythology, and about temperament-the great issue of the thirties. In her autobiography Mead writes about the heated discussions of those days in the bush in New Guinea:

In my own thinking I drew on the work of Jung, especially his fourfold scheme for grouping human beings as psychological types, each related to the others in a complementary way. Gregory, who tended to use biological analogues, invoked the formal patterns of Mendelian inheritance.

As we progressed, we tried to work out patterns within a fourfold scheme and to place the cultures we knew best in terms of the temperamental type-or types-emphasized in each culture as a whole. In doing so, we came to the conclusion that there must be one kind of culture of which we had no good example. I made a guess that Bali would exemplify that missing type. When at last we went to Bali, it turned out that my guess was an accurate one. ${ }^{55}$

But in fact her guess was not only not right, it was not about psychology at all. Though she didn't seem to mind the difference, the research in Bali was about psychiatry. About psychiatry in worried America.

America in the 1930s thinks that schizophrenia, then often called dementia praecox, is on the increase. A Committee for the Research into Dementia Praecox is established, and it asks scientists how research into schizophrenia must be performed. Mead writes a proposal which is rejected. Yet she plans to carry it out and she raises the funds to do so. The proposal is the result of talks with Jane Belo, a self-made anthropologist who lives in Bali with her husband Colin McPhee, a musicologist. Jane Belo is on leave in America in 1934 where she meets Mead whom she knows slightly from her college days. She tells Mead about Bali and she presents "such complete and fascinating segments of Balinese culture that it seemed the ideal culture within which to plan a project on the cultural aspects of schizophrenia." 56

How did Belo depict Bali to Mead? Belo described Balinese culture as rich and beautiful, but also as a ritual performed by reticent people who suppress their emotions. Yet the Balinese are contented, happy, and balanced: "The Balinese are a people whose everyday behavior is measured, controlled, graceful, tranquil," observes Belo in her book Trance in Bali. ${ }^{57}$ But it is not Belo, it is Mead and Bateson who make the connection between Belo's description and schizophrenia. Bateson, a biologist who had done some anthropologist-like research in New Guinea among the Sepik, adds his ideas to Mead's who is the dominant theorist of their joint Bali expedition. ${ }^{58}$ The expedition was to take two years of their life. Yet the material on which it was based was-to put it mildly-scarce. "We had chosen Bali," writes Mead in her autobiography, "with knowl-

\footnotetext{
${ }^{54}$ Howard, Margaret Mead, p. 161; Mead, Blackberry Winter, pp. 235 ff.

${ }^{55}$ Mead, Blackberry Winter, p. 238.

${ }^{56}$ Margaret Mead's preface in: Jane Belo, Trance in Bali (New York: Columbia University Press, 1960), p. i.

57 Belo, Trance in Bali, p. 1.

${ }^{58}$ Mead, Blackberry Winter, p. 258: "When Gregory was working in latmul he invented the term schizogenesis, a concept that was later identified as positive feedback (...) In Bali, he added the concept of zygogenesis, in which acceleration leads not to a breaking point but to a harmonious equilibrium."
} 
edge and forethought as the culture we wanted to study ... in order to obtain material on one temperamental emphasis we had only hypothesized must exist. We had seen just enough material in films and still photographs, had heard just enough of the music studied by Colin McPhee, and had just read enough in Jane Belo's careful records of the ceremonies with which the Balinese greeted the terrible disaster of the birth of twins to assure us that this was the culture we wanted to work on."59

But in another place she admits that it was a "fragmentary knowledge of Balinese culture," she and Bateson possessed, adding: "Many years before I had seen some films on trance dancing. And in 1934 Jane Belo, whom I had known since she was a student at Barnard, brought me some very interesting materials from Bali, where she had been living."60 Mead has also read Bali and Angkor, the idealizing description of the island by her good friend Geoffrey Gorer. But Mead and Bateson are, and remain, ignorant of the manifold older descriptions in which Balinese are pictured as anything but tranquil and emotionally suppressed: these are from the eighteenth, nineteenth, and even twentieth century travelers in Bali. In these reports the Balinese are not impersonal, reticent, tranquil, measured, or controlled. On the contrary, in the precolonial and early colonial stories and reports the women are portrayed as beautiful but horribly exploited by their men. Balinese men are reported to be strikingly robust, even boisterous, freedom-loving, money-conscious, noisy, open, belligerent, and devoid of any submissiveness to the white man to whom they sell their own people as slaves. Happy they are as well, in particular when provided with opium and fighting cocks. ${ }^{61}$ And these people have suddenly by the mid-1930s become collectively schizophrenic? No wonder educated Balinese people like I Made Kaler wonder what Mead and Bateson are after. And I Made Kaler has never stopped wondering. Till today he is grateful that Mead and Bateson taught him so much while working with him. But schizophrenia? As the common Balinese disease?

Mead and Bateson's hypothesis sounded ultramodern in the 1930s. Once arrived in Bali, shortly after her divorce from Fortune and her marriage with Bateson, Mead is to test it out on her fellow whites on Bali: Belo, Spies, Colin McPhee, Claire Holt, Katharane Mershon, and Beryl de Zoete. They are not entirely antipathetic: the concept of the Balinese as people completely different from Westerners and yet so special and venerable does of course appeal to them because it shows the "otherness" of the Balinese which is why they are in Bali. Spies, to whom they all owe much, has taught them about the "above-ness" of the Balinese who don't worry about money, jealousy, politics, and love as Westerners do. So Mead and Bateson are well received: "The Europeans we met were, many of them, artists and dancers and musicians who had come to Bali for months, sometimes for years, to paint or write or simply to delight in the painting and dancing of the Balinese. Instead of feeling helpless, as we so often did in New Guinea, to communicate to Europeans the simple fact that the native people among whom one had come to work were as real as their colonial administrators and had minds as able and affections

\footnotetext{
${ }^{59}$ Ibid., p. 246.

${ }^{60}$ Mead, Letters from the Field, p. 153.

${ }^{61}$ Schulte Nordholt, Bali: Colonial Conception, pp. 11 ff.; Julius Jacobs, Eenigen tijd onder de Baliërs (Batavia: Kolff, 1883); H. H. van Kol, Driemaal dwars door Sumatra en zwerftochten door Bali (Rotterdam: Brusse, 1914). For a survey of travelers accounts of Bali: James A. Boon, The Anthropological Romance of Bali 1597-1972 (Cambridge: Cambridge University Press, 1977). See also: Wim Bakker, Bali verbeeld (Delft: Volkenkundig Museum Nusantara, 1985); Geoffrey Robinson, "The State and Civil War in Bali 1880-1965, A Political History" (draft of PhD thesis, Cornell University, 1988), ch. 5.
} 
as passionate as theirs, we encountered in Bali continuing active interest and enjoyment. It made little difference whether we talked with a visitor like Beryl de Zoete, or with those who, like Walter Spies and Jane Belo, had built themselves homes in Bali. In their houses they brought together carvings from one village, wall paintings from another, and musicians still from another. And as Bali changed, as new materials were used and new themes appeared in paintings and dances, artist residents both enjoyed and guided, criticized and facilitated, so that standards of the new forms were high." Mead and Bateson seem to fit in nicely.

But things go wrong. The European crowd around Spies is hostile to the methods the newly arrived scholars use. Mead and Bateson, for example, measure the length of a trance with a stopwatch. But the methods are in fact the minor point. The assumption that the Balinese are all schizoid is the real issue. Paradise-like Bali-is paradise because it has no problems, let alone bad mental health. Spies, a strong personality, seems to be slightly amused but also indifferent to the hypothesis that all Balinese are essentially schizoid-it doesn't threaten him in his own views. The others do mind. Irritation grows, and after two months in the South Mead and Bateson decide to move away, to a so-called Bali-Aga village in the mountains, to detect the deepest layers of Balinese civilization. The notion of Bali-Aga as the supposed cultural base of Bali stems from traditional Dutch scholarship and cannot have been withheld from Mead and Bateson in their discourses with Goris, Spies, and C. J. Grader, another learned Dutchman who is a colonial civil servant and a good friend of Spies. But Mead is, when moving to "her" Bali-Aga village, obviously so hurt that she writes, quite conceited about their first two months in the festive South: "While we feasted on riches, day after day, and found each temple, each theatrical performance, and each shadow play more delightful and more intelligible than the last; we searched for a village. We had made a decision that contravened the usual approach of Europeans to the high cultures of the East.... We would approach Balinese culture as we were accustomed to approaching a primitive culture, by using our eyes and ears. We would not pore over ancient texts or dictionaries in which the roots of words had been laboriously traced by Dutch scholars or rely on erudite comparisons which were alien to the villagers themselves."62 Yet relations with Spies remain good; it is Spies again who commands a work force to build Mead and Bateson a house in the village Bajung Gde. They rent a terrain the size of ten sites of normal village houses. The house is nice, big, and airy. And Mead feels obliged to Spies; he is her "artist-host" and she confesses that she has a problem contradicting him. As she later on will have a problem contradicting Jane Belo whom she feels to be her other artist-host.

So there is tension in the air. Not so much with Spies who is independent enough not to mind other people's theories, but with the others. The stay in the Bali-Aga village in Bajung Gde brings no relief. Native life in the mountains is poor, dull, unceremonious, uncultural, quarrelsome, and sour. The natives blackmail the white foreigners who have to pay for everything, information included. The solitude is not easy to bear, especially not when the jet-set in the South is known to be there. After four months of isolation Mead and Bateson give up: they go, at least part-time, back to the South where the other whites live, in their "luxurious houses" and in the nice company of the warm, friendly, civilized people of caste. ${ }^{63}$ But they keep their spacious newly built house with its many pavilions in Bajung Gde. In the South they rent half of the palace of the former Raja of Bangli-"about nine dollars a month and it has three golden doors." They have

${ }^{62}$ Mead, Blackberry Winter, pp. 250-51, 253-54.

${ }^{63} \mathrm{Mead}$, Letters from the Field, pp. 211, 187. 
eight servants and a car. Katharane Mershon moves into the other part of the palace. And they adapt to the rhythm of white life in Bali. But yet they don't feel good. They don't know how to relax. They commute now between Bajung and Bangli. Sometimes Bajung Gde seems preferable to everything else, and when in the South Mead complains about

the recurrent contacts with Europeans, always the most trying thing in the tropics. In Bali there is as much gossip as anywhere else, but it is all in artistic terms.

We got a lot done and came back to Bajoeng very sure that we prefer our cool mountain top and no visitors and no motorcars, even if our village people are sulky and frightened and dressed in rags. At least we know them and can work ahead withouf fever or haste or prima donnas or Medicis.

Yet it doesn't take much time before they decide that Medicis and prima donnas are at least interesting people, and so they move back again, this time renting a third house. The house is in Batuan, a village of Brahman painters. The village is a center of white interest; Mead and Bateson meet many people, keep in touch with especially Mershon who does research into dance, and all the moving and roving appears to be too tiring:

We are in Bangli which, after the last months in Bajoeng, is almost like a direct move to Heaven. It is of course the Balinese type of heaven for Hell is located in exactly the same locality. So at any time we may have to get into a car and go to fifteen ceremonies at once, encounter shopping in Den Passar or tourists and the trails left by tourists in the homes and tempers of our friends. But at this moment we are at peace.

They're seldom alone. Just married, they seek no seclusion. They hurry and are harassed from painter to trance-dance, from ceremony to gamelan, and they measure, make notes, translate, make photos and films, and after Mead leaves Bali in 1938 she writes in a rather chaotic letter to Boas:

When I said I was going to Bali, you said: "If I were going to Bali, I would study gesture." And that is one of the things we have tried to do. We have accumulated a mass of photographic material [Bateson took 25,000 photographs] stills and Ciné, on everyday activities and on the more stylized ones, such as dancing, cockfighting, prayer and trance gestures, and so on. We have about 1,000 little grotesque carvings which are full of points about posture and balance. We have children and adolescents doing the same kinds of things. It is the sort of problem that needs fine analysis at home, especially time to project and study the Ciné film. Jane Belo, McPhee and Mrs. Mershon (who has lived here for eight years) have done a lot of work on special projects for us also. With three native secretaries, that has meant seven persons' careful records on selected events. I am still not perfectly clear in my mind about the problem of tackling these complex cultures and the legitimacy of different types of cross-sectioning. But we have tried to assemble as many types of cross-sectioning as possible, so that we have material for studying the same ceremony in different areas, the complete set of ceremonies for one area, and studies of topics like trance, theatricals and painting which crosscut areas altogether.

She then was as exhausted as her summing up is exhaustive. And she knew Boas was not going to be satisfied, not in spite of, but because she and Bateson had amassed such a 
lot of things without a clear idea of what to do with it. And she adds: "I know you think I go into the field too much in proportion to writing up." 64

Two years she has been in Bali. The period is cut into two by the return from America of Belo in early 1937. The return does Mead no good. Belo criticizes her and Bateson as "cold and analytical."65 More important: Belo has no confidence at all in the schizophrenia hypothesis. They quarrel. Beryl de Zoete, never a friend of Mead, enjoys the fight: "Beryl, who had an acid tongue and a gift for destructive criticism, effectively satirized this conflict between science and art, and I identified her with the witch, a prevailing Balinese figure. And so, periodically, I would note moments of special felicity in my diary with the initials r.p., which stood for ranga padem-the witch is dead-and conveyed my feeling that the influence of Beryl and the malign influences of Balinese culture, which emphasized nameless fear as a sanction, were temporarily in abeyance."66 Mead's fear of being rejected is acute. Her anxiety as well: twice she is pregnant, twice it ends in a miscarriage. 67

But the conflict can't go on forever. Spies, always everybody's elder brother, intervenes and restores peace. The result is that Mead hands over the trance research to Belo. ${ }^{68}$ She and Bateson now specialize on paintings (Bateson), ceremonies (both), and children (Mead and also Bateson). Everything seems under control. But under whose control? Mead and Bateson, writes Mead later, now convert their former enemies into active collaborators: they now work in the field with Mershon, McPhee, Spies, de Zoete, Grader, Goris, and in particular with Belo. "We developed a research plan for work in Bali that would also involve Jane Belo and her musician husband Colin McPhee," writes Mead later. ${ }^{69}$

But the collaboration is not an easy one. Jane Belo, an independent person, displays the courage to oppose Mead and Bateson. ${ }^{70}$ She differs with Mead and Bateson in opinions about trance and Bali; Jane Belo adheres to the traditional view that trance is not a collective characteristic of a people, but a state of mind of a few in many cultures. Mead, on the other hand, has the quite dashing idea that in Bali everybody knows from personal experience what trance is about: trance, she thinks, is an alibi to express emotions that in daily life are suppressed, and as emotions in all Balinese are suppressed, everybody has at least trance-like experiences. This is their hypothesis, and they are so convinced of its value that very soon after their arrival they act on it. Within two months of Nyepi 1936 they make a film of trance dance. Mead recounts later, in her autobiography: "One of our most successful films was made when we ordered a group to play in the daytime that ordinarily performed only late at night. We had no movie lights and we wanted to film the different ways in which men and and women handled their razor-sharp krises in the trance dances when they turned the kris, in mock selfdestruction, against their own bodies. The man who made the arrangements decided to substitute young beautiful women for the withered old women who performed at night,

\footnotetext{
${ }^{64}$ Mead, Letters from the Field, p. 195, p. 200, p. 212.

${ }^{65}$ Mead, Blackberry Winter, p. 253.

${ }^{66}$ Ibid.

67Ibid., p. 269.

68. Mead, "Preface," in Belo, Trance in Bali.

${ }^{69}$ Mead, Letters from the Field, p. 153.

70Interview with Prof. Hildred Geertz, Batuan, Bali, May 1986.
} 
and we could record how women who had never before been in trance flawlessly replicated the customary behavior they had watched all their lives."71

So "normal" Balinese were not normal at all-they identified "flawlessly" with professional trance dancers who were supposed to be severely disturbed.

The anecdote carries still another message: all Balinese are essentially the same. Differentiation makes no sense. That message fits with contemporary views on "primitive" people. Rouffaer had considered Bali an unstratified society. Spies, reared by Goris in the Rouffaer school, had done the same-all Balinese are artists.

And so Mead writes to Franz Boas in March 1938: "It has been customary to say that the mountain villages of Bali are almost completely different from the higher culture of the Plains, and yet in analysis the basic patterns turn out to be almost identical. Records of conversation between a Brahman priest and a man who wants to marry his daughter are almost verbatim the same as conversations between two mountain peasants to their babies. So one of the things we hope to do is to lay down the pattern of Balinese culture, in skeleton, in the such a way that the different flesh of the different caste and economic and local variations may be put in relevantly." And "relevantly" means in this case, as we have seen, a typical Dutch inspired colonial phrase about how difficult it is to be a member of the affluent minority in Bali-a minority which had Mead's clear preference (we "welcome the warmth and assurance of the high castes").72

And the sameness of all Balinese fitted into the theory of Boas as well. In fact, it had very much to do with the German scholarly tradition of the anthropology of customs of which not only Mead, but many scholars from Boas' stable, were the inheritors. The essence of Boas' work had, despite emigration to America, remained German, writes Adam Kuper in his book The Invention of Primitive Society; the folklore studies of Grimm, romanticizing and authenticating an already changing world into the much wished-for "steady state" are the living example of his German tradition. ${ }^{73}$ What added to this inheritance which influenced Mead was that Spies too was essentially German: embodying the "schwärming" romantic folklore-lover who really wants to be the native's best friend and has at the same time the reactionary traits of his species.

The sameness of all Balinese as artists, which Spies in the tradition of Rouffaer and others proclaims, enables Mead and Bateson to say that all Balinese are schizoid. An open-air museum or an open-air asylum-the difference is not that big.

Balinese Character is the title of the book in which Mead and Bateson in 1942 describe their fieldwork. The book pretends not to be about custom, but about real life, about "the Balinese-the way in which they, as living persons, moving, standing, eating, sleeping, dancing, and going into trance, embody that abstraction which (after we have abstracted it) we technically call culture."74 And yet it is a book about custom. It must, however, have gone against the grain of Boas because "psycho-analysis he would have no traffic with," as A. L. Kroeber writes so pointedly. ${ }^{75}$ Why is Balinese Character a book like a dead weight? Because we miss the living Balinese, mentally sick or not, in it.

\footnotetext{
${ }^{71}$ Mead, Blackberry Winter, pp. 252-53.

${ }^{72}$ Mead, Letters from the Field, pp. 213, 214, 211.

${ }^{73}$ Adam Kuper, The Invention of Primitive Society, Transformations of an Illusion (London: Routledge, 1988), pp. $125 \mathrm{ff}$.

${ }^{74}$ Bateson and Mead, Balinese Character p. xii.

${ }^{75}$ A. L. Kroeber's Preface in Anthropology of Franz Boas, ed. Goldschmidt, p. vi.
} 
As a clinical book, of course, it had to fail: Mead and Bateson were not equipped at all for psychoanalytical research. They were not trained in psychiatry, nor did they speak Balinese well. They relied on their power of observation and on photography as the new medium for field-workers, and that was insufficient. The research of the psychoanalyst, as his therapy, is about the individual and his words, not about the gestures or images of a collective. So a clinical study it was not. But as a report on life the book is a failure as well: the villagers of Bajung Gde, poor peasants, mistrusted Mead and Bateson. They pressed them for financial support for upkeep of the village, but they didn't open their compounds to them. In these circumstances, taking photographs of people acting spontaneously was impossible. Yet the photographs had to prove the central point: Balinese mothers are cruel to their children. Since, of the many thousands of photographs taken in Bajung Gde only a few hundred are printed in Balinese Character, the text in the book has to do the rest.

The main body of the text is written by Mead. Bateson took care of the photographs and wrote the illustrating texts for which Mead's long introduction is the background. Mead's main themes are impersonality and cruelty.

Typical Balinese cruelty, she explains, consists of two elements: encouraging fear in children, and frustrating aroused childish emotions.

Fear is her first issue. Fear in Bali, she writes, originates in the mother's slendang: the baby on her hip feels the panic of the fear-stricken mother, and internalizes it. But the mother also frightens the child on purpose, in particular when the child is about one and a half years old and can walk:

As the child grows old enough to run away, to get into mischief, to meddle with the belongings of others, or to upset food cooking on the fire, the mother pantomimes the fear which the child has already experienced so often in her arms. Like an old hen clucking in panic to call her chicks back under her wing, the mother of the straying child gives a histrionic fear-laden cry, "Aroh!" followed by the mention of any one of a dozen scare symbols, chosen at random and without any concern for their relevance-_"Fire!" "Snake!" "Feces!" "Scorpion!" "Witch!" "Elf spirits!" "White man!" "Chinaman!" "Policeman!" "Tiger!" The mother is as likely to exclaim "Fire!" when the baby toddles into a possibly snake-infested banana patch; "Feces!" when it touches the betel basket of a visitor, and "Tiger!" when it crawls under the bed. There is no reality content in the whole performance. The child responds only to the startled fear in his mother's voice, and to the theatrical embrace in which she holds him when he runs back to her. This is almost the only occasion on which the mother meets the child emotionally, giving him her complete, although theatrical, attention. This practice lays the groundwork for the continuation of fear as a major sanction and stimulus in Balinese life. It lays the groundwork for an ambivalent attitude toward fear, an emotion which the Balinese cultivates as well as yields to, and for the open preference for theatricals and theatrical behavior which is so characteristic of the Balinese. Only in the theater is the overt expression of emotion permitted. In real life, the European is often at a loss to tell when two Balinese are quarreling, but on the stage, emotions are so accurately delineated that no mistake is possible. ${ }^{76}$

The fact that Mead, like other "Europeans," could not distinguish peace from quarrel in Balinese conversation didn't in her own eyes discredit her for psychiatric research.

76 Bateson and Mead, Balinese Character p.31. 
Neither did she question her own motives-she, who was very much longing for a child and had had several miscarriages, describes the Balinese mother as a person who wants from visitors not an emotional attachment to her child but a "theatrical" "cooing and gurgling." The Balinese mother rejects the "real emotion," i.e., the emotion that Mead offers to the Balinese children. It makes Mead feel rejected and angry. ${ }^{77}$ Mead's hostility to the Balinese women ("old hen"), badly concealed by her admittance that these women too must have undergone an ordeal of fear if they are inspiring so much fear in their children, shimmers through the pages. She considers men to be the victim of Balinese women, as she had discovered the elite of high-caste to be the real victim of the caste system. Balinese women, she writes, are essentially frigid, as wives and as mothers. This, added to the inspiring of fear in children, is the source of Balinese schizophrenia. Not to be able to reach a climax is the Balinese disease and it is acquired in childhood.

Parallel to the development of fear and its theatrical presentation, the Balinese baby is subjected to a peculiarity of the mother-child relationship which is apparent when the child is only five or six months old and which becomes steadily more definite as the child grows older. This is a series of broken sequences, of unreached climaxes. The mother continually stimulates the child to show emotion-love, or desire, jealousy or anger-only to turn away, to break the thread, as the child, in rising passion, makes a demand for some emotional response on her part. When the baby fails to nurse, the mother tickles his lips with her nipple, only to look away uninterested, no slightest nerve attending, as soon as the baby's lips close firmly and it begins to suck. She sets her baby in her bath-after six months this is a round tub-and teasingly thrusts her fingers between his lips, only to look away, disassociated, as the baby bites delightedly at her hand. She hands her baby to another woman, and then threatens to leave him, "I'm off home! You I will leave," but when the baby bursts into tears, her attention has already wandered and she takes him without looking at him, as she comments to her sister on the price of beans in the nearest market.

As the child gets older, from about eighteen months on, the teasing, the stimulus to the never realized climax becomes more patterned and more intense. For the little ruffle at his genital, she substitutes a sudden sharp pull; the little girl who was chucked under the chin or patted lightly on the vulva with a gay "Pretty! Pretty!" is now poked in the abdomen. The mother borrows the babies of others with which to tease her own, by setting the stranger, younger baby over the head of her own, or giving it the breast. But she never plays the scene through. If her own child falls into a tantrum she suddenly hands him the borrowed baby, but then, just as he is ready to throw his arms around her neck, she will take it again or start a conversation with a neighbor. ${ }^{78}$

"The mother, and in line with the mother, the aunt, the sister, and the child nurse tease and tantalize, while the child responds with mounting emotion which is invariably undercut before the climax. Later, the child begins to withdraw. This withdrawal may coincide with weaning, it may precede it, or it may follow it." The withdrawal Mead sketches, is not the withdrawal of the toddler as we know it in European culture, it marks the end of childhood and of emotional development, so that the result is an adult living the life of a sulky four-year-old: it is

\footnotetext{
77Ibid., pp. 31-32.

${ }^{78}$ Ibid., p. 32.
} 
a withdrawal of all responsiveness. The mother borrows the neighbor's baby, but her child looks on unmoved. He skirts any group in which he thinks there will be someone to reach out a hand towards him. And once established, his unresponsiveness will last through life.

Most children reach this state by the time they are three or four, vacillating at times, falling into deep sulks or violent tempers, only to resume again their newly acquired imperviousness. For girls this change usually coincides with their taking up the role of child nurse, and starting to carry a baby everywhere with them. For boys, it coincides with the beginning of herding-following older boys to the fields with the oxen in Bajoeng Gede, or with the water buffalo in Batoean.79

Leaving aside the question as to whether bearing the responsibility for babies and oxen and buffalo at a toddler's age didn't make a tough upbringing a bare necessity of life, Mead omits in her exposé the crucial question: was Balinese upbringing really different from that in Samoa, Java, or any other island in the Southeast Asian sphere? In fact the similarity between her description of childhood in Bali and of that in Samoa is striking, differing only in interpretation-what is healthy in Samoa, like a child's refusal to play with an American toy brought by Mead, is sick behavior in Bali. But apart from that, was the upbringing in Java, only a one-day sailing from Bali, not exactly like that in Bali? Or was life for young children in Java even harder? The Javanese, traditionally perceived as more difficult to approach and scrutinize than the Balinese, must, according to Mead's hypothesis, have been exposed to even more cruelty than the Balinese child. Javanese culture should, as a consequence, have had all the traits of Balinese culture, but more aggrandized. Though "the essence of anthropological work is comparison," as Mead states in her autobiography, ${ }^{80}$ she didn't make comparisons of this kind or any other. Apart from a few remarks about peoples in New Guinea, she never refers to any other culture. And she had a good reason not to do so. The results of her research were so confused, the materials so abundant, and the trance research such a disaster that comparison with other research was simply impossible. ${ }^{81}$

Yet she and Bateson wrote Balinese Character to explain why the Balinese, despite their awful childhood, live a balanced life in their essentially "good society." 82

The crux was Balinese culture. Culture made up for craziness-although it was inspired by craziness as well. This affirmed what the Boasian school taught: that every people selects from wide possibilities to create a culture from those parts that suit it best. So culture functions as the cause of the illness, the cure of it, and as the prophylactic against it. Given the-by biologists and physicians presupposed but unexplainedincrease in schizophrenia, people must change their culture to adapt to new diseases. That, in fact, is the message for America in Mead's writings about Bali. But as provoking as it was to prescribe more sexual freedom for the American youngster as the medicine against puberty, her remedy against the social burdens of schizophrenia is lame: people in the American country town had better play more amateur theater together to prevent

\footnotetext{
${ }^{79}$ Ibid., p. 33.

${ }^{80}$ Mead, Blackberry Winter, p. 259.

${ }^{81}$ Mead, Letters from the Field, pp. 203, 213.

${ }^{82}$ Mead, "Arts in Bali," in Traditional Balinese Culture, ed. Belo, p. 340.
} 
mental illnesses. ${ }^{83}$ That is Mead's advice, the meager result derived from her expedition to Bali where theater is an essential part of life.

For Mead, never a very artistic person, the Balinese theater had more to do with the session of the psychotherapist than with a cultural phenomenon. She explains the theater as the all-Balinese cure of the all-Balinese disease: "While the Balinese child is passing through this first period of responding with passion to his mother's gay, disassociated teasing ... he is also the spectator of the drama in which the Balinese express their feelings about such a mother-role. The Witch play, the Tjalonarang, the definitive dramatic theme of Balinese parent-child relations, not only expresses the residue in the adults of what they experienced as children, but also is watched by children and shapes their reading of the experiences to which they are subjected daily. It colors the child's appreciation of his mother's behavior, and stylizes his attitude toward her."84 This experience, she writes in another essay, is not damaging to the child, but healing, because it brings into the open what otherwise would have remained rotting in the child's mind: "for every tension in the threads which have been twisted or doublewoven in the delicate mesh of the child's spirit, the culture has a symbolic relaxation ready. And so Bali is a good society, meeting the more elaborated needs of its elaborately patterned members." 85

Now why does the performance of the witch in the Tjalonarong give such a "symbolic relaxation" to people?

Mead describes Tjalonarong as a play in which the witch plays an important and remarkable role. And all the more remarkable because, at least in the story as Mead repeats it to her readers, the Witch is indeed an angry woman, but a good mother transforming herself into a witch to attack the bad king who has mistreated her daughter. So much for Mead's insistence that the play is the mirror of frustrated relation between mothers and children. So much, too, for Mead's insistence ("the besetting fear" of each Balinese male that he will after all marry the Witch). In Mead's opinion the witch is played out to give release to Balinese men's bitterness about their wives: the play, being about maternal attitudes, is not about marital relations.

It is a myth, a metaphor, about the eternal struggle of powers to arrange the world in such a way that love and triumph get reconciled. The lesson of the myth is that abduction leads to nothing: the abductor steals a girl, but in his haste he takes the ugly one instead of the beautiful one with him. ${ }^{86}$ To read in it, as Mead does, the resentment of the Balinese man who discovers after marriage that he has not married a lover, but an itchy, bitchy housewife fits not into the play, but into Mead's unkind treatment of the, in fact, often over-burdened Balinese woman who suffered then, as she does now, from frequent childbirth and from the gambling of cock-fighting husbands.

But even if Mead and Bateson had understood what Balinese mythology is at least not about, would they have been right in viewing mythology (or, in general, culture) as the mirror of people's frustrations and people's frustrations as the mirror of their own culture? Apart from the question of what use culture is if it is only a mirror of our daily lives, there is another problem: how to ascertain that it is a mirror? Roger Keesing, in

\footnotetext{
${ }^{83}$ Mead, "Community Drama, Bali and America," in ibid., p. 349.

${ }^{84}$ Bateson and Mead, Balinese Character, p. 34.

${ }^{85}$ Mead, "Arts in Bali," pp. 331-40.

${ }^{86}$ Bateson and Mead, Balinese Character, pp. 35-36.
} 
his 1981 edition of Cultural Anthropology, has explained why Culture and Personality research makes no sense. Psychoanalytical terms and ideas are not culture-proof, he writes, so there is no way to test Western conceptions of the presupposedly psychological conditions of other hemispheres. The researcher may use koala bears from a toy shop in New York, as Mead and Bateson did in Bali, or Rohrschach tests from a psychological laboratory as Mead did in New Guinea, the response of informants will never fit convincingly into the frame of reference of the researchers. And if they seemingly do, the interpretation is likely to be wrong. So Karba, the boy in Bajung Gede, who was Mead and Bateson's fitting example of the frustrated child, appeared not to be typical for Bajung Gede at all. When revisited as an adult, he had the appearance and the reputation of being an unusually sulky, unresponsive person. And so it had to be, because the methodology of the Culture and Personality school in essence is the vicious circle: culture explains psyche, psyche explains culture. The only problem is that Karba shows that it doesn't work that way. ${ }^{87}$

Mead didn't really like Bali. In her essays she pretends to, but in her letters home she pictures the Balinese as dour, dull, apathetic, quarrelsome, and childish. Their culture is an empty one "an art to which the individual executant has often contributed nothing but skill." The religion, she states, was "largely negative in its working; there are things to be done \& if you don't do them trouble will come." Though in public enhancing the belief in the blessings of Balinese continuity and tradition, in private she would write: "not an ounce of free intelligence or free libido in the whole culture.... The whole culture is arranged like a sling, and most of the time the people swing in it, their knees barely gripping, working alone, without either punch or kick... . Anything new or strange leads to total panic." 88 The people are not only unfree, but rather stupid as well-as Mead wrote in her letters home, as well as in Balinese Character, a book for the scholar and not for the larger audience. They make utterly meaningless talk to each other all the time, they don't know (nyonya Besar's classic complaint) how to carry out an order consisting of more than two elements.

Balinese learn nothing from verbal instruction, are seldom concentrated when at work, they suffer from a very rigid orientation in time and space, their interpersonal relations lack any real emotion, but are "strict and formal," and "thoughtfulness implying as it does identification with the other, is extraordinarily out of Balinese character." Balinese relate to their own body and to the world around them as impersonal fragmented human beings whose bodily feeling never involves the whole of their physique and whose mind concentrates on a segmentized body. Babies are their dolls, puppets who are no more than an extension of their mother's limbs. Fighting-cocks fulfill the same functions for men. Being so withdrawn into a fragmented self, identification of the spectator of a play with the characters on the stage is impossible. Nor has the spectator any emotional communication with the man or woman standing near him looking at the spectacle. The thrill of fright looking at the witch and her counterparts is the only real emotion they feel and for which they find an outlet in their enthusiastic and noisy participation in what happens in the play. But often a spectator can be seen standing aside from the crowd, smiling his schizoid dream. Waves of "awayness" make any Bali-

\footnotetext{
${ }^{87}$ Roger M. Keesing, Cultural Anthropology (New York and Madrid: Holt, Rinehart, \& Winston, 1981), pp. 365 ff.

${ }^{88}$ Howard, Margaret Mead, pp. 200, 198, 193.
} 
nese from time to time unapproachable. But that too fades away-in Bali things never come to a climax. ${ }^{89}$

So Balinese are crazy. There is one person who takes the initiative to disprove this. Jane Belo, in the late 1930s, invites the leading Dutch psychiatrist Dr. P. M. van Wulfften Palthe to Bali. Van Wulfften Palthe, who works in Java, is aware of the dangers of ethno-centric psychoanalytical research. He has written about "amok" and is believed to be an expert in his field. Intrigued by Belo's opposition to Mead and Bateson's research, he does research on Balinese trance and in 1940 writes the article "Over de bezeetenheid" ("About being possessed") in the leading Dutch medical journal. Balinese are not schizoid, is his conclusion. And the capacity to go into trance is not a collective trait of the Balinese people. ${ }^{90}$ Mead and Bateson, who must have heard from Belo about the contents of the article even if they may not have seen the text, don't mention it. Even in their bibliography of Balinese Character it is not to be found.

Mead and Bateson's research has been repeated in the 1980s by Gordon Jensen, an American psychiatrist, and Luh Ketut Suryani, a Balinese anthropologist. Their findings, not yet published but summarized in a newspaper article,, 91 stress that Mead and Bateson were wrong in their interpretation of the "teasing," frustrating mother: the idea of not giving in to the wishes of the child is to teach the child the restraint which is characteristic of the avoidance society. In this society, so difficult to understand for the Westerner, climaxes as well as personal relationships do exist, but are, like quarrels, easily overlooked by the foreigner. "Awayness" is indeed an existing phenomenon, but means concentration and a short interval of self-hypnosis in which people remain sensitive to stimuli of others. Not clear is whether Jensen and Luh Ketut Suryani view the "Balinese Character" as unique as did Mead and Bateson.

The most surprising thing about Mead and Bateson's descriptions of Bali is not their psychoanalytical approach. That was part of the Culture and Personality school. What is surprising about their writings is that they share the eulogizing tone in which their contemporaries wrote about Bali as "dream-island," "the last paradise," "island of the gods." This tone is not dominant in Balinese Character which is a scholarly book. But it is in the articles Mead wrote for a larger audience, in which Balinese life is pictured as not only suitable to Balinese needs but as the paradise Spies, Belo, and the others wanted it to be. Instead of poor, dull, acultural Bajung Gede with its poor, terrorized people, whose fate, Mead stressed, could be generalized ${ }^{92}$ for nearly all Balinese:

Here was an almost incredible busyness; day and night, the roads were full of people walking with a light and swinging step under heavy loads; the air was never empty of music, even in the small hours before the dawn; and it was not the mere woodland piping but complicated orchestrated music which bore witness to many hours of concentrated rehearsal. Upon the hundreds of stone altars of Bali, there lay not merely a fruit and a flower, placed as a visible prayer to the many gods, but hundreds of finely wrought and elaborately conceived offerings made of palm leaf and flowers, twisted, folded, stitched, embroidered, brocaded into myriad traditional forms and fancies. There were flowers made of sugar and combined into representations of the rainbow, and swords and spears cut from the snow-white fat of sacrificial pigs. The

\footnotetext{
${ }^{89}$ Bateson and Mead, Balinese Character, pp. 2-5, 8, 12, 25-28, 15-17 ff., 39.

${ }^{90}$ Belo, Trance in Bali, pp. $5 \mathrm{ff}$.

${ }^{91}$ Kompas, May 16, 1989.
} 
whole world was patterned, from the hillsides elaborately terraced to give the maximum rice yield to the air which was shot through with music, the temple gates festooned with temporary palm-leaf arras over their permanent carved façade to the crowd of the people who, as they lounged, watching an opera or clustered about two fighting cocks, composed themselves into a frieze. The most casual and unanalytic tourist recognized that these people were contented and gay not because they lived in a salubrious climate, where they could find food without work and love without responsibility, but because their lives were packed with intricate and formal delights. And the tourist wondered. For wasn't his own life full, crowded with striving and effort?-yet he was not content. What difference was it between the Balinese way of packing the hours and our ways that brought them contentment and relaxation to which music and dancing and gay laughter are the natural accompaniment, while we had so much strain and fatigue, grumbling and discontent, and weariness of living. ${ }^{93}$ won. ${ }^{94}$

Happy, happy Balinese who were above all such feelings. Yes, Walter Spies really

92 Bateson and Mead, Balinese Character, p. xiv.

${ }^{93}$ Mead, "Arts in Bali," p. 333.

${ }^{94} \mathrm{Mead}$ and Bateson left Bali at the beginning of 1938. They divorced in 1950, after being separated for many years. Walter Spies died when a Japanese bomb hit the "Van Imhoff," a Dutch ship on which Germans living in Dutch East Indies, were interned and transported after the outbreak of the second World War. The "Van Imhoff" was on its way to India where the British planned to intern white citizens allied with the Axis powers. The last time Mead and Spies met each other was in Bali, at the beginning of 1939. Mead and Bateson had returned to Bali to assist friends, including Belo, who were the victims of the razzia on European homosexuals ordered by the Dutch Governor-General. Bobbie Mörzer Bruyns, who was alerted, fled in time. Spies was interned. Belo was interrogated. Colin Mc Phee left Bali. So did many others, or as Belo says: "at least half the European people living in Bali have been asked to leave, or have left on their own accord ... one dares not wonder why." Howard, Margaret Mead, p. 210. 
